\title{
Assessment of trace elements natural enrichment in topsoil by some Italian case studies
}

\author{
Giuseppe Sappa $^{1} \cdot$ Maurizio Barbieri $^{2}$ (D) Francesca Andrei $^{1}$
}

Received: 7 April 2020 / Accepted: 15 July 2020 / Published online: 22 July 2020

(C) The Author(s) 2020 OPEN

\begin{abstract}
Trace elements (for example $\mathrm{As}, \mathrm{V}, \mathrm{Cr}, \mathrm{Ni}, \mathrm{Cu}, \mathrm{Z}, \mathrm{Cd}$ and $\mathrm{Pb}$ ) released by human activity are ubiquitously detected in topsoil. They can be conveyed from the topsoil to the ecosystem, thus affecting human health. Also, trace elements are not sensitive to any process of decomposition in soils and the bioavailability is complicated due to the reactive nature of soil constituent. The goal of this assessment is to present a methodology able to evaluate the topsoil trace elements natural enrichment and distinguish between geogenic phenomena and anthropogenic contributions. This paper presents some Italian case studies in Lombardy and Lazio. The potential pollution risks of trace elements in topsoil were evaluated by geoaccumulation index $\left(I_{\text {geo }}\right)$ and enrichment factor. The results show an absence of anthropogenic contamination, highlighting the need to consider the local characteristics (landfills, municipal solid waste plants, industrial areas, quarries, etc.). Moreover, a statistical method (cumulative frequency and normalization method) was presented to determine the geochemical baseline values. In the case of Borgo Montello (Lazio), manganese is used as a relative element due to its high presence in soils. The proposed geochemical baseline values of $\mathrm{V}, \mathrm{Cr}$, $\mathrm{Co}$ and $\mathrm{Ni}$ thorough normalization method were, respectively, $123.07,82.10,9.41$ and $29.70 \mathrm{mg} \mathrm{kg}^{-1}$, instead by cumulative frequency the results were $78.24,84.10$, 6.67 and $23.70 \mathrm{mg} \mathrm{kg}^{-1}$. This methodology shows a potential validity to define the geochemical baseline values, but it is necessary many data $(n \geq 40)$ and distributed homogeneously over the study area.
\end{abstract}

Keywords Trace elements · Geoaccumulation index $\left(I_{\text {geo }}\right) \cdot$ Enrichment factor $(E F) \cdot$ Topsoil contamination · Geochemical baseline concentrations - Geogenic enrichment

\section{Introduction}

Soil acts as an immobilizing system of trace elements, checking their passing to the groundwater. However, this ability is a function of the physic-chemical soil properties and environmental requirements [1,2]. Usually, heavy metals, such as As, V, Cr, Ni, Cu, Z, Cd and Pb, occur naturally as "trace" in soil $\left(<1000 \mathrm{mg} \mathrm{kg}^{-1}\right)$ by pedogenetic processes of parent materials, but also by some human activities and industrial processes, such as land application of fertilizers or pesticides, presence of landfills, disposal of high metal wastes, municipal solid waste plants, mine tailings, coal combustion residues, etc. [3, 4]. Generally, the surface sediments hold more heavy metal of the than the waterbody, so it is necessary to examine their contents in the surface sediments [5, 6]. Normally, the highest levels of trace elements originated from the parent rock are chromium, manganese, nickel, cobalt, copper, zinc and lead. Instead, arsenic, cadmium and mercury are usually present at deficient concentrations $[7,8]$. In the environmental sector, trace elements are ubiquitous due to some phenomena such as chemical adsorption and physical precipitation

\footnotetext{
$\triangle$ Maurizio Barbieri, maurizio.barbieri@uniroma1.it; Giuseppe Sappa, giuseppe.sappa@uniroma1.it; Francesca Andrei, francesca.andrei@uniroma1.it | ${ }^{1}$ Department of Civil, Building and Environmental Engineering (DICEA), Sapienza University of Rome, Rome, Italy. ${ }^{2}$ Department of Earth Sciences (DST), Sapienza University of Rome, Rome, Italy.
} 
in the sediments of groundwater. These phenomena can cause changes in the water or sediments condition in terms of $\mathrm{pH}$, electrical conductivity (EC), oxidation-reduction potential (ORP), and chemical oxygen demand (COD) [9-11]. However, these can cause changes for chemical forms (speciation) and bioavailability of trace elements [3]. These changes can pose risks and hazards to humans and ecosystem, through direct ingestion or contact with contaminated soil, the food chain, drinking of contaminated groundwater, reduction in food quality via phytotoxicity and in land usability for agricultural production causing food insecurity [12]. Therefore, a global environmental issue results due to the crucial importance of food production and security. So, it is necessary an adequate protection and restoration of soil ecosystems contaminated by heavy metals [3]. The calculation of environmental geochemical baselines is necessary to assess the soil pollution status and to provide guidelines and quality standards in environmental legislation, especially for the evaluation of contaminated soils and environmental risk assessment [13]. However, the geochemical baseline assessment is complex and not always possible, so this paper proposes a statistical procedure to determine the geochemical baseline values. The statistical approach (cumulative frequency and normalization method) proposed, combined with the evaluation of two pollution indicators (geoaccumulation index and enrichment factor), allow to establish the soil pollution status.

\subsection{Soil pollution status: the definition of background value (BVs) and geochemical baseline concentrations (GBCs)}

The geo-availability controls the behavior of trace elements geogenic in soils. It is the fraction of the total content of a chemical element that can be freed to the environment by mechanical, chemical, or biological processes. Generally, the anthropogenic sources cause the more mobility of heavy metals in the soil than pedogenic or lithogenic ones [14]. In order to determine if a soil is polluted, it is essential to characterize trace elements presence for geogenic or anthropogenic sources [15]. The measurement of the rates of trace elements in the soil surface horizons cannot provide evidence about the soil contamination status, because not support the distinction between natural background and anthropogenic enrichment [16]. In fact, it is necessary to define:

- Background value (BVs): natural contents of substance in the soil dependent on the compositional and mineralogical characteristic of the parent/source geological material;
- Geochemical baseline concentrations (GBCs): concentration range of an element in a specific area dependent both on the parent geological/source material and on the historic diffuse release $[17,18]$.

The former one represents the natural concentrations of an element in the soil [19], a measure performed to differentiate between the natural compound concentrations and the concentrations with an anthropogenic influence on an environmental sample [20]. Once the natural background of the metals has been defined, the geochemical anomaly is defined as the deviation of the metal content from the limit value defined by the legislation [21]. The background value depends on the geological substrates, and the natural processes performed the soils [22]. Still, due to atmospheric deposition that can contaminate soils with certain trace elements, it is almost impossible to learn natural background levels [23, 24]. It is difficult to determine the background value in areas subject to anthropogenic influence or marked by high spatial variability of the pedological/geological characteristics of the soils. Moreover, the absence of information relating to the soil geochemical composition in a study area is also a strong limit for the assessment of soil contamination. The definition of the natural background, often, occurs by international reference values, but they derived from other studies and the reference may cause severe uncertainty. Therefore, the geochemical baseline concentration assessment is more useful, since it represents conditions where a certain human impact on the environment already exists [25]. As already mentioned, the geochemical baseline concentrations include the geogenic natural content and the anthropogenic contribution in the soils $[17,18]$. However, a geochemical baseline should be determined separately for each trace elements in the study area, otherwise the limit values for contaminated soils may be lower than the natural concentrations calculated for an extensive area [26]. Although referring to a Regional Geochemical Baseline Mapping is a valid procedure, it would be better to determine the local geochemical baseline, because it is more representative since the trace elements anomalous values recorded to particular sites could be geogenic [2]. In fact, to determine local geochemical baseline, its necessary sampling of topsoil at depths not exceeding $1 \mathrm{~m}$ of soils (subsurface horizon) [15, 27, 28]. The surface layers (from 0 to $20 \mathrm{~cm}$ ) provided more information on the pollution levels caused by the geogenic processes of soil formation or anthropogenic sources. Instead, the subsurface layers (from 40 to $100 \mathrm{~cm}$ ) exclusively represent the lithogenic contributions, since there is little probability of contamination through atmospheric deposition, and for this reason the subsurface horizon can be used to 
determine the local geochemical baseline [13]. In the hypothesis that it is not possible to carry out a subsurface soil horizon samples and the Regional Geochemical Baseline Mapping is not available, some studies [29-31] identify statistical methods (cumulative frequency and normalization method) as useful tools to define the geochemical baseline values. In order to assess the soil pollution status, some studies [28, 32-36] use some quantitative indexes: the geoaccumulation index $\left(I_{\text {geo }}\right)$ and the enrichment factor (EF). By comparing the concentrations of a trace element in the topsoil and the locally natural background for the study area, these indexes allow the "health of a soil" assessment. These indexes identify, numerically, pollution level soils and normally they are calculated on the soil exchangeable fraction because it represents the real bioavailable fraction. The bioavailable metal content in soil exerts a decisive impact on soil quality and it is used in food production [16]. This fraction is obtained by applying the first step of Tessier et al. [37] procedure and optimized by Frankowsky et al. [38]. The objectives of this paper are:

- to define a procedure able to evaluate the soil contamination status, by some Italian case studies in Lombardy and Lazio;

- to assess the exchangeable fraction of topsoil, associated with the calculation of the geoaccumulation index $\left(I_{\text {geo }}\right)$ and metals enrichment factor (EF);

- to propose a statistical approach to estimate the geochemical baseline values.

\section{Proposed method}

The pollution by trace elements is one of the most critical environmental risks to health. Generally, trace elements can be present at low concentrations $\left(\mathrm{mg} \mathrm{kg}^{-1}\right)$ in soils, but sometimes, they can be toxic to the environment. The Environmental Protection Agency (EPA) has presented a table of pollutants with some trace elements, such as silver, arsenic, beryllium, cadmium, chromium, copper, mercury, nickel, lead, antimony, selenium, thallium and zinc. Among these elements, the most widespread in contaminated soils are $\mathrm{As}, \mathrm{Cd}, \mathrm{Cr}, \mathrm{Cu}, \mathrm{Hg}, \mathrm{Pb}$, and $\mathrm{Zn}$ [2]. Contamination is linked to the presence of a substance, for example, a trace element, at concentrations higher than the natural background values, because the contaminants are dangerous only under specific conditions in the environment [39]. Once an element passed from soil to water, to be hazardous it must be found in abnormal concentrations, i.e. higher than naturally background values. In the environment, the element could be available, and the hazard will depend on its "bioavailability". It is the degree to which a contaminant is possible to uptake in soil or groundwater, i.e. the movement into or onto an organism [40]. Hence, it seems useful to show a method to assess trace elements concentration in soils and to explain their presence due to natural enrichment or anthropogenic contamination (Fig. 1).

Firstly, the study area must be presented, highlighting the geological and hydrogeological settings. In order to characterize an area, it is also important to consider the study area location: the presence of infrastructure,

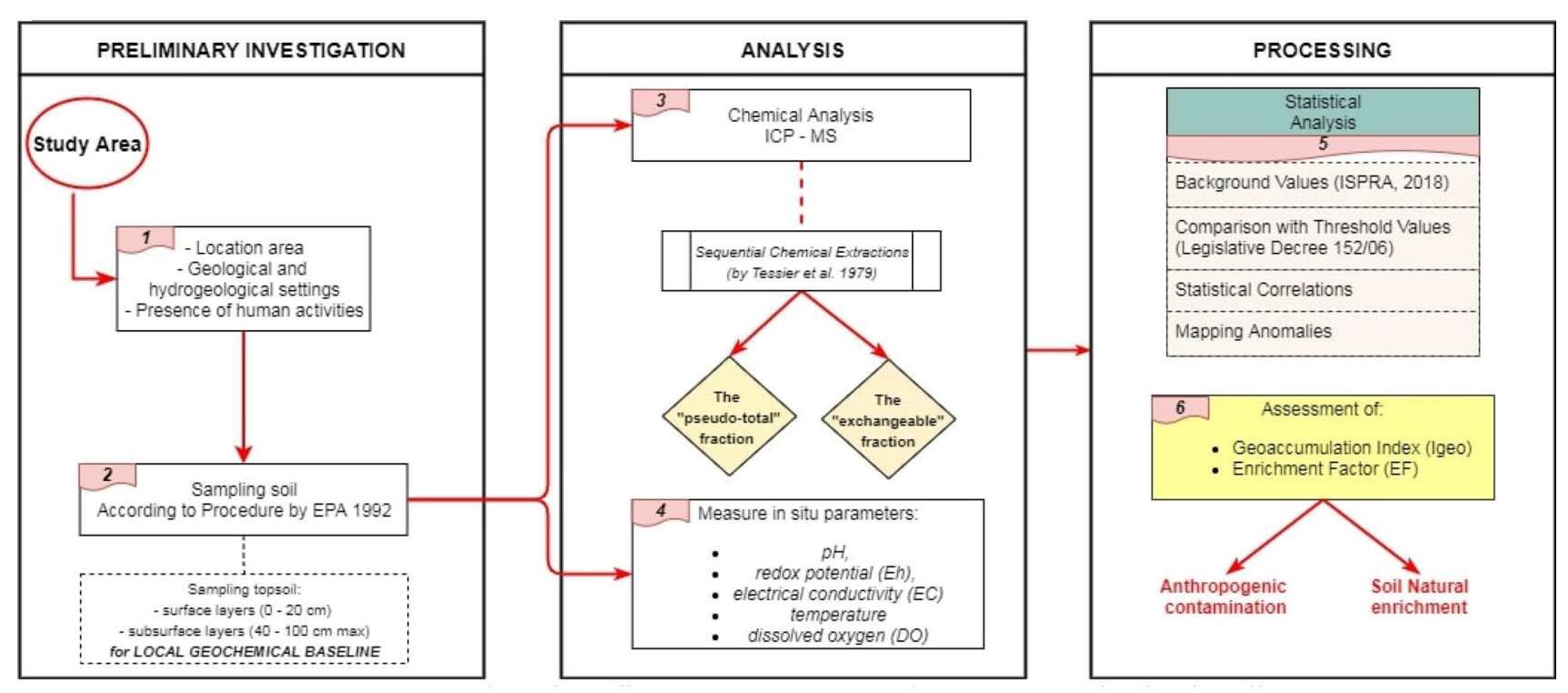

Fig. 1 Flow-sheet diagram to assess trace elements contamination in soils 
industrial areas, quarries or mining areas, land uses, agricultural areas, plants. In order to assess the soil contamination by trace elements, a sampling survey should be performed according to Italian government regulation. At the laboratory, chemical analysis is followed by inductively coupled plasma mass spectrometry (ICP-MS). The trace elements distribution and their relative mobility in the different soil phases can be pursued through extraction method, specifically sequential chemical extractions. The method uses different specific extractants, based on complex reactions. The result is an operational speciation leading to the trace elements mobility and their partitioning into the main soil phases [37]. In order to assess environmental issues, this method allows the determination of "total" (aqua regia extraction) and "exchangeable" (acetic acid, ammonium acetate and ethylenediaminetetraacetate-EDTA extraction) fraction of trace elements. The "exchangeable" fraction represents the real bioavailable fraction on the soils $[2,16]$. Then, the proposed method considers some in situ parameters: $\mathrm{pH}$, redox potential (Eh), electrical conductivity (EC), temperature ( $T$ ) and dissolved oxygen (DO). These parameters, in fact, may undergo variations due to trace elements concentrations beyond the threshold values by Italian Legislative Decree $152 / 06$. In order to study the trace elements distribution in the soils, a statistical analysis is necessary, that allows: (1) to compare the trace elements concentrations with the threshold values of Italian Legislative Decree 152/06, (2) to define background values, according to ISPRA Procedure [41], (3) to verify the spatial and temporal distribution of trace elements concentrations, (4) to perform statistical correlations between the trace elements concentrations (Boxplot diagram, Spearman correlations) and correlations also with the chemical-physical elements. The proposed method, at the end, identifies geoaccumulation index $\left(I_{\text {geo }}\right)$ and enrichment factor (EF) as useful tools to assess the potential pollution risks of trace elements in the soil. These indexes, defined on the bioavailable fraction of the trace elements, can give an indication if the contamination is due to anthropogenic causes or natural enrichment, therefore linked to geogenic phenomena occurring locally.

\section{Materials and methods}

\subsection{Sampling and chemical analysis}

Sampling is a basic phase of each environmental assessment and the results quality is closely linked to the sampling itself. It is therefore a complex step affecting the results of all subsequent operations. Therefore, it is necessary to prepare a Sampling Plan aimed at collecting representative samples for a correct contamination phenomena evaluation. The following method is widely used in environmental geochemistry and recommended by Italian government regulation. In general, to assess the topsoil natural enrichment, the samples are collected to a maximum depth of $30 \mathrm{~cm}$ from the surface. At the laboratory, soil samples were placed in plastic containers and dried at a constant temperature of about $40^{\circ} \mathrm{C}$. Once dry, the samples were sieved manually using a $2 \mathrm{~mm}$ mesh sieve. Chemical analysis is performed on a fraction of soil $(\varnothing<2 \mathrm{~mm})$, according to the Legislative Decree 120/2017. For each soil sample, a granulometric fraction of less than $2 \mathrm{~mm}$ weighing $1 \mathrm{~g}$ is powdered using an agate mortar [42]. The chemical analysis is followed by Thermo Scientific Application Note 40619 (US EPA SW-846 Method 6020A Using the XSERIES 2 ICP-MS). The solubilization procedure by "acqua regia" $\left(\mathrm{HCl}-\mathrm{HNO}_{3}\right)$ allows to determine "pseudototal" content of trace elements. It can enable the estimation of the maximum amounts of trace elements that are potentially available or mobile in soils, in fact it does not dissolve silicate matrices [43]. The procedure uses $250 \mathrm{mg}$ of soil sample and it mixes with $9 \mathrm{ml}$ of $\mathrm{HCl}$ plus $3 \mathrm{ml}$ of $\mathrm{HNO}_{3}$ ("aqua regia") and placed on a hot plate at $50^{\circ} \mathrm{C}$ for $2 \mathrm{~h}$. Once the solubilization is performed and cooled for $20 \mathrm{~min}$, the concentrations of minor and trace elements are measured using an ICP-MS (X Series 2, Thermo Fisher Scientific) following filtration $(0.45 \mu \mathrm{m})$ and acidification in the field $\left(\mathrm{HNO}_{3}, 3 \%\right)$. The analytical accuracy of these methods ranged from 2 to $5 \%$. An internal standard, $\mathrm{Rh}$, was used to correct the ICP-MS instrumental drift. Ultrapure water (Millipore, Milli-Q, $16 \mathrm{M} \mathrm{X} \mathrm{cm}$ ) was used to prepare blanks, standard solutions and sample dilutions [37]. Instead, there are a lot of methods to define "exchangeable" fraction of trace elements, such as calcium chloride $\left(\mathrm{CaCl}_{2}\right)$, calcium nitrate $\left(\mathrm{Ca}\left(\mathrm{NO}_{3}\right)_{2}\right)$, ammonium nitrate $\left(\mathrm{NH}_{4} \mathrm{NO}_{3}\right)$ or ammonium acetate $\left(\mathrm{CH}_{3} \mathrm{COONH}{ }_{4}\right)[44$, 45]. It allows to assess the mobility and availability of trace elements in soils. Once the solubilization is performed, the concentrations of trace elements can be measured using an ICP-MS (X Series 2, Thermo Fisher Scientific). On the contrary solubilization procedure by "acqua regia", the definition of "exchangeable" fraction is not required by Italian government regulation.

\subsection{Geochemical baseline values assessment}

In order to assess the soil pollution, it is necessary to define Geochemical Baseline Values in the study area. Some studies [29-31] have shown the need to use statistical methods to determine the geochemical baseline values. According to Zhou et al. [29], the used statistical approach considers the combination between the cumulative frequency curve (CFD) and the normalization method through a linear 
regression. A cumulative frequency distribution (CFD) curve is plotted. The curve is generally characterized by:

- Two inflexions. In this case, the lower data represents the upper limit of natural origin concentrations and the higher ones are the limit of abnormal concentrations. The extreme points are deleted until the remaining data meet the criteria for the linear regression $\left(R^{2}>0.95\right)$. These data are selected as average metal concentrations to define local geochemical baseline;

- One inflexion. In this case, the geochemical baseline is obtained from the data below the inflexion value;

- No inflexion. If the curve is approximately linear, all the data are used to calculate the baseline.

According to some studies [29-31], the geochemical baseline is defined by arithmetic mean or median value. For the normalization method, a conservative reference element is selected because they are not influenced by anthropogenic inputs. Generally, the commonly used reference elements are: aluminum, iron, manganese, rubidium and scandium $[46,47]$. The normalization method involves a linear regression equation between " $n$ " trace element $\left(C_{n}\right)$ and the reference element $\left(C_{\text {ref }}\right)$ by following way:

$C_{n}=a * C_{\text {ref }}+b$

where $a$ and $b$ are regression constants. In Eq. (1), the natural sediment is defined by the data points falling inside the $95 \%$ confidence band. Instead, data falling outside the $95 \%$ confidence band reflect probably anthropogenic input [31, 32]. Data points inside the $95 \%$ confidence band are used to calculate the geochemical baseline of " $n$ " trace element $\left(B_{n}\right)$ as follows:

$B_{n}=c * \bar{C}_{\text {ref }}+d$

where $\bar{C}_{\text {ref }}$ is the mean concentration of the reference element. The geochemical baseline value at each sampling site can be calculated according to Eq. (2). A high dataset with a greater number of data, with a homogeneous distribution over the study area, makes the use of the statistical method more effective, stable and statistically valid.

\subsection{Pollution indicators}

Some pollution indices can be used to provide a relative ranking of contamination levels. In fact, geoaccumulation index $\left(I_{\text {geo }}\right)$ and enrichment factor (EF) can be employed to assess the pollution status and to estimate the impact of anthropogenic activities [16, 33, 48-50]. These indicators are used to assess the presence and intensity of anthropogenic contaminant on topsoil. They are calculated by the normalization of a trace element concentration in the topsoil respect to the concentration of a reference element [16].

\subsection{1 $I_{\text {geo }}$ values}

The geoaccumulation index $\left(I_{\text {geo }}\right)$ has been used since the 1970 s as a measure of contamination of bottom sediments [51] and has been used evaluating the contamination of trace elements on soils [16, 52-54]. It is used to evaluate enrichment of the upper horizons respect to "local background". The $I_{\text {geo }}$ was calculated (in the fraction $\leq 2 \mu \mathrm{m}$ ) by following way:

$I_{\text {geo }}=\ln \left(\frac{C n}{1.5 * B_{n}}\right)$

where $C_{n}$ is the concentration of " $n$ " trace element in topsoil and $B_{n}$ is the geochemical background concentration of " $n$ " trace element. The factor 1.5 is the background matrix correction factor due to lithogenic effects and anthropogenic influence. According to Muller [55], the geoaccumulation index $\left(I_{\text {geo }}\right)$ consists of 7 classes: unpolluted $\left(I_{\text {geo }} \leq 0\right)$, unpolluted to moderately polluted $\left(0<I_{\text {geo }} \leq 1\right)$, moderately polluted $\left(1<I_{\text {geo }} \leq 2\right)$, moderately to heavily polluted $\left(2<I_{\text {geo }} \leq 3\right)$, heavily polluted $\left(3<l_{\text {geo }} \leq 4\right)$, heavily to extremely polluted $\left(4<l_{\text {geo }} \leq 5\right)$, or extremely polluted $\left(I_{\text {geo }} \geq 5\right)$.

\subsubsection{Enrichment factor}

The enrichment factor (EF) is used to identify the contribution of anthropogenic sources in topsoil [56]. The enrichment factor is expressed as follows:

$\mathrm{EF}=\frac{\left(C_{n} / C_{\text {ref }}\right)}{\left(B_{n} / B_{\text {ref }}\right)}$

where $C_{n}$ is the concentration of the " $n$ " trace element in topsoil, $C_{\text {ref }}$ is the concentration of reference element in topsoil sample, $B_{n}$ is the geochemical background concentration of the " $n$ " trace element in topsoil (background value) and $B_{\text {ref }}$ is the geochemical background concentration of reference element in topsoil sample. In fact, this index allows to evaluate the variation of a potentially toxic element respect to a reference element. A reference element is an element particularly stable in the soil, which is characterized by absence of vertical mobility and/or degradation phenomena. The commonly used reference elements are: aluminum, iron, manganese, rubidium and scandium [46, 47]. According to Zhang et al. [57], EF values between 0.05 and 1.5 indicate that the trace elements enrichment is due to crustal materials or natural processes, 
whereas EF values higher than 1.5 suggest that the contamination is linked to be anthropogenic sources. In fact, generally the soils can be classified as deficiency to minimal enrichment $(E F<2)$, moderate enrichment $(2 \leq E F<5)$, significant enrichment $(5 \leq \mathrm{EF}<20)$, very high enrichment $(20 \leq \mathrm{EF}<40)$ or extremely high enrichment $(\mathrm{EF} \geq 40)$ [47].

\section{Results}

This paper presents some Italian case studies: (1) the Bevera Valley Basin (Lombardy), (2) the Appian Way Regional Park, located in the center of the city of Rome (Lazio), (3) Borgo Montello and Cisterna di Latina in Pontina Plain, located to the southeast of Rome (Lazio) and (4) Roccasecca located within Latina Valley (Lazio).

\subsection{The Bevera Valley Basin in Lombardy}

The Bevera Valley Basin is located in the Municipality of Arcisate (VA), in the northeast part of Lombardy Region (Fig. 2). In the southeast part of the Municipality of Arcisate, there are three big quarrying areas: Rainer Quarry and Femar Quarry, both non-operative since the 90s, and Valli Quarry (operative).

During the sampling survey, from April 2017 to March 2018, the Arsenic, Manganese and Iron concentrations in groundwater exceeded the threshold values of the Italian Legislative Decree 152/2006. In order to verify possible interactions with groundwater, two topsoil samplings were performed in Rainer Quarry and Femar Quarry and they were analyzed according to procedure by Italian Legislative Decree 152/2006 (Fig. 3).

Figure 3 shows an analogy of the trends in the two quarries. The trends are linked, in fact, to the common geological origin of soil constituting two deposits, with high values for aluminum and iron.

\subsection{Case studies in Lazio region}

The studied areas are the Appian Way Regional Park (RM), Borgo Montello (LT), Cisterna di Latina (LT) and Roccasecca (FR) (Fig. 4). In southeast Rome, there is the Appian Way Regional Park, located in an urban environment within the Campagna Romana. This area is mainly characterized by pyroclastic deposits, coming from the Tosco-Laziale volcanic activity. The second and third areas are localized in the Pontina Plain, at the southeast of Rome, positioned in the geologically transitional zone between the Lazio volcanic deposits and the terrigenous coastal deposits [58]. Roccasecca, instead, is situated inside the Latina Valley and it is characterized mainly by alluvial deposits. Borgo Montello, Cisterna di Latina and Roccasecca are positioned near landfill sites [35].

The topsoil units were selected: 9 samples were collected in the Appian Way Regional Park (Fig. 5), 16 samples in Borgo Montello (Fig. 6), 10 samples in Cisterna di Latina (Fig. 7), and 5 samples in Roccasecca (Fig. 8). The concentrations of $\mathrm{V}, \mathrm{Mn}, \mathrm{Fe}, \mathrm{Co}, \mathrm{Ni}, \mathrm{Cu}, \mathrm{As}, \mathrm{Cd}$ and $\mathrm{Pb}$ in topsoil and background samples were analyzed.

Figure 5 shows that in topsoil samples the $\mathrm{Al}, \mathrm{Fe}$ and $\mathrm{Mn}$ trace elements have high concentrations. Instead,
Fig. 2 Localization of Arcisate (VA) in the northeast part of Lombardy Region

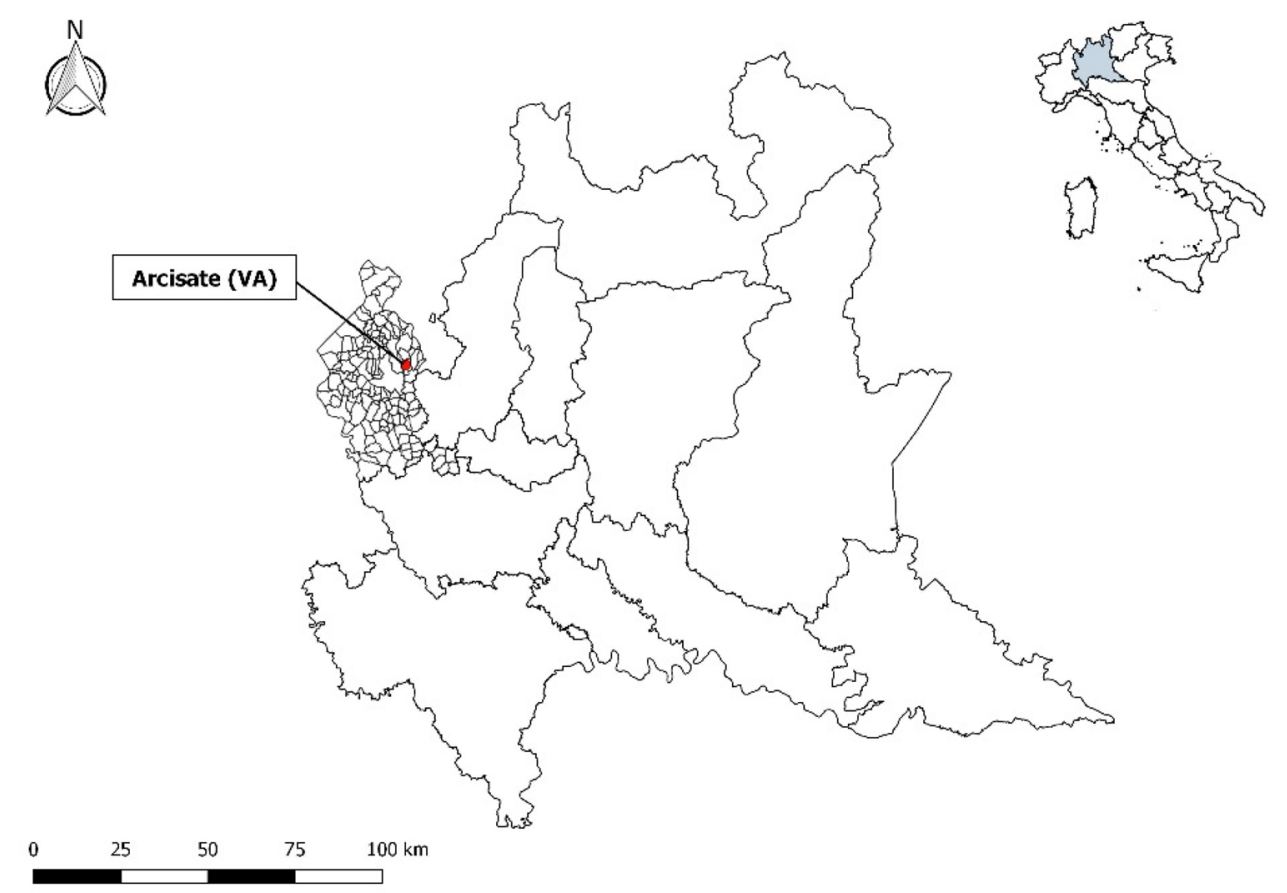


Fig. 3 Trend concentrations trace elements for Rainer and Femar Quarry

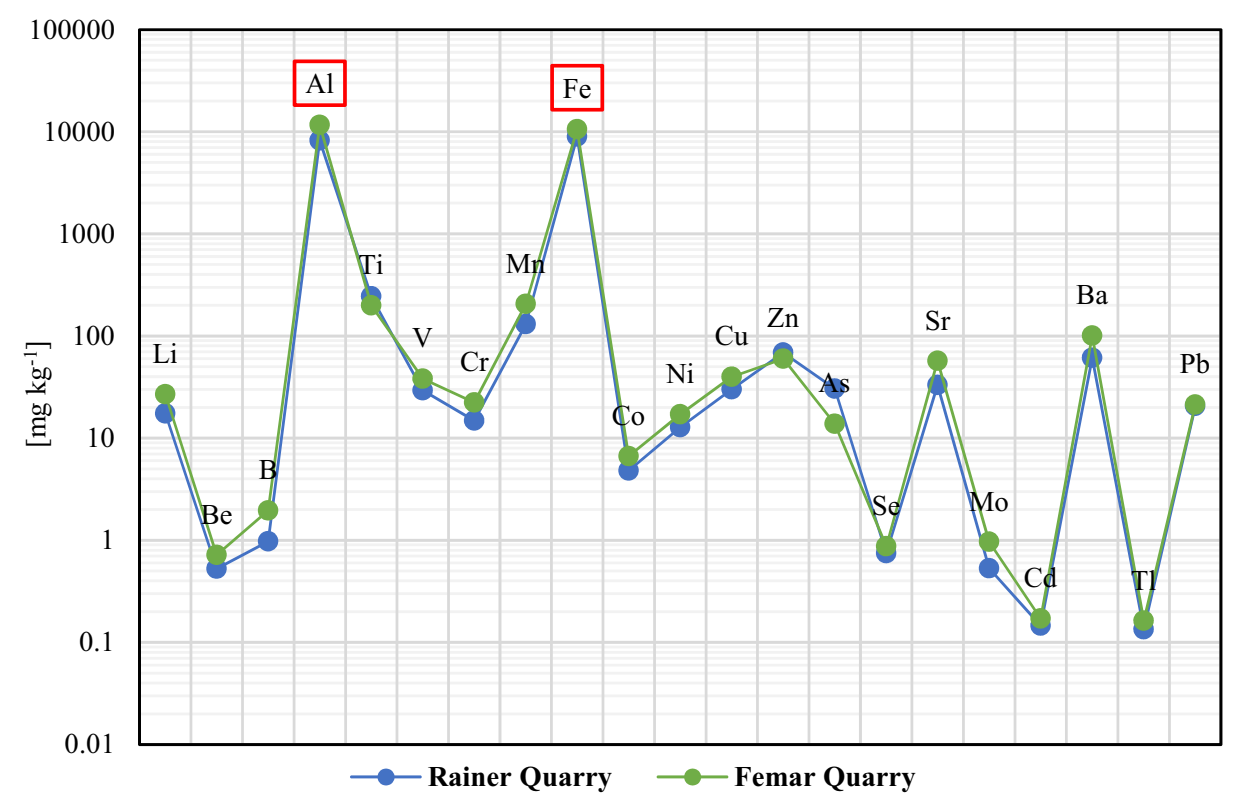

No
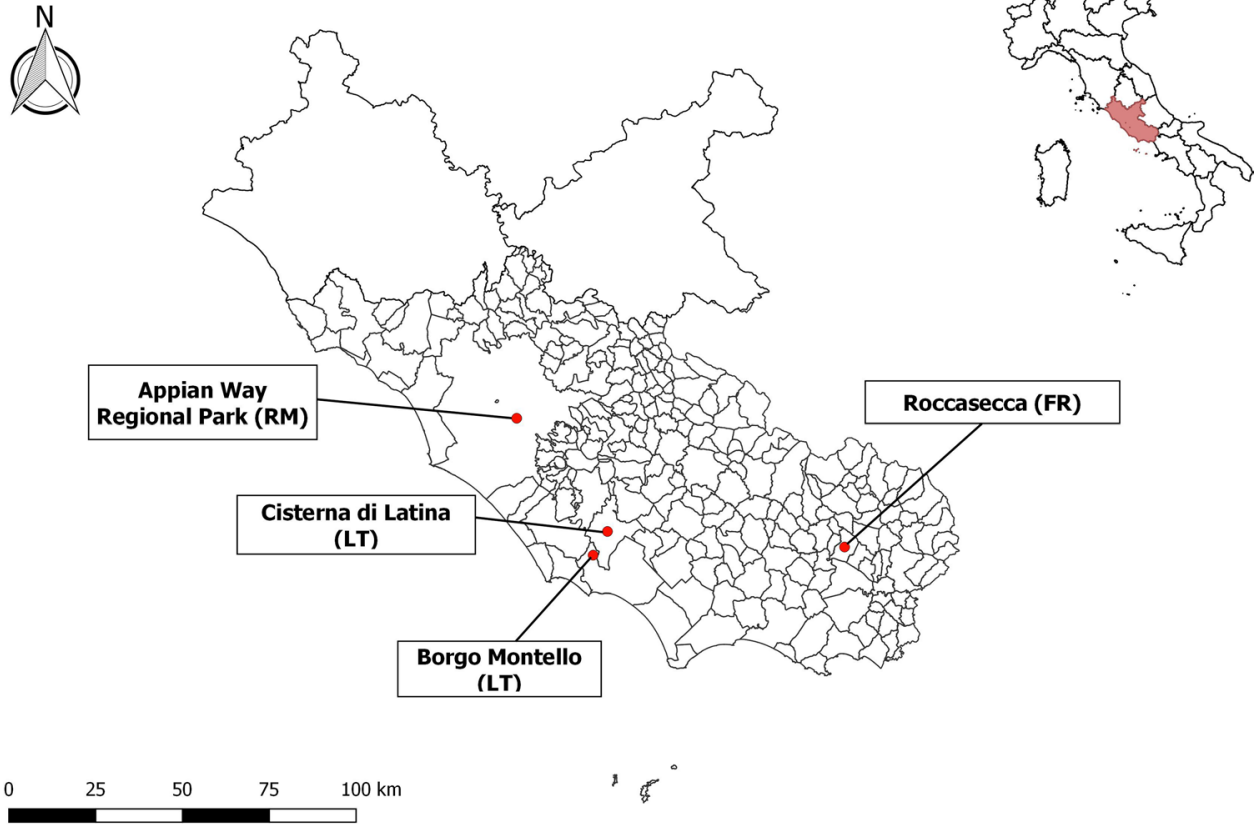

Fig. 4 Localization of case studies in Lazio Region low values of $\mathrm{Cd}$ are showed in all samples, with concentrations lower than $1 \mathrm{mg} \mathrm{kg}^{-1}$.

Like the trace elements concentrations trend of Appian Way soils, Al, Fe and Mn are the major concentrations detected in Borgo Montello area (Fig. 6). Furthermore, $\mathrm{Cd}$ concentrations are lower than $1 \mathrm{mg} \mathrm{kg}^{-1}$.

The results (Fig. 7) for Cisterna di Latina topsoil indicate that $\mathrm{Al}, \mathrm{Fe}$ and $\mathrm{Mn}$ are the main constituents, with low values for $\mathrm{Cd}$.
Figure 8 shows that $\mathrm{Fe}$ and $\mathrm{Mn}$ are also the main constituents of the Roccasecca topsoil, with Cd concentrations lower than $1 \mathrm{mg} \mathrm{kg}^{-1}$. Figures 5, 6, 7 and 8 show similar trend of trace elements concentrations for topsoil samples in each considered case studies, with high values of manganese, iron and aluminum. These elements are associated to soil origin; in fact, these are common constituents of soils especially for soil of sedimentary deposits [59]. 
Fig. 5 Trend concentrations trace elements in the Appian Way Regional Park
Fig. 6 Trend concentrations trace elements in Borgo Montello
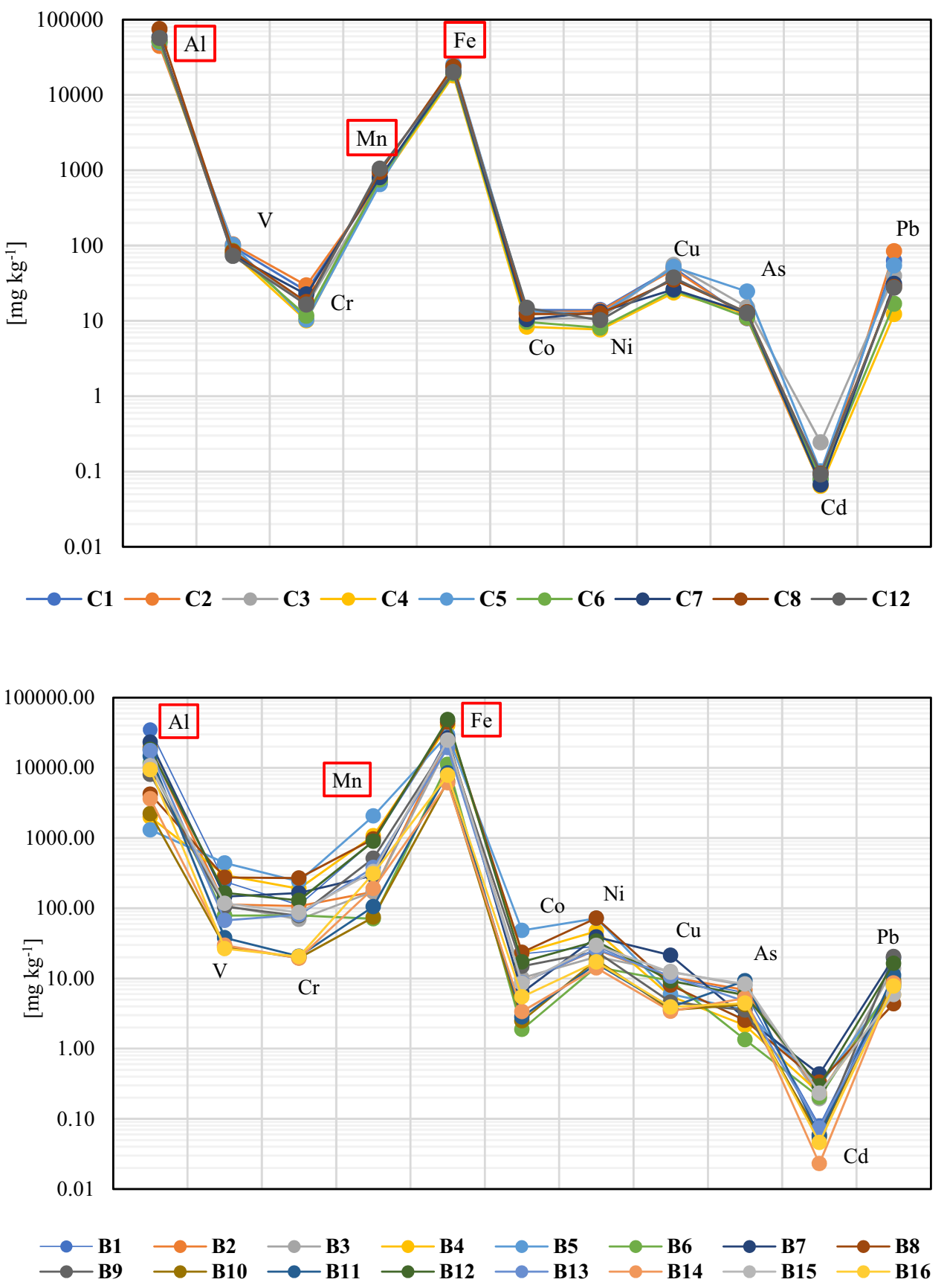

\section{Discussions}

The potential pollution risks of trace elements in topsoil were evaluated by method of geoaccumulation index $\left(I_{\text {geo }}\right)$ and enrichment factor analysis (EF). The objective is verify that some trace elements (i.e. $\mathrm{As}, \mathrm{V}, \mathrm{Cr}, \mathrm{Ni}, \mathrm{Cu}$, $\mathrm{Co}, \mathrm{Cd}$ and $\mathrm{Pb}$ ) with higher concentration in topsoil samples compared to the background values can be possibly linked to some anthropogenic activities in addition to the content from parent soils.

\subsection{The Bevera Valley Basin in Lombardy}

Negative values of Geoaccumulation Index suggest that the trace metals may be entirely from natural weathering processes [57]. Instead, an $I_{\text {geo }}>0$ value indicates that a portion of the trace metals derives from non-crustal materials [47], for example by pollution sources. Table 1 shows the results of the Geoaccumulation Index in Rainer and Femar quarries.

The $I_{\text {geo }}$ results (Table 1) highlight the absence of contamination, with negative values, for Rainer and Femar 
Fig. 7 Trend concentrations trace elements in Cisterna di Latina
Fig. 8 Trend concentrations trace elements in Roccasecca
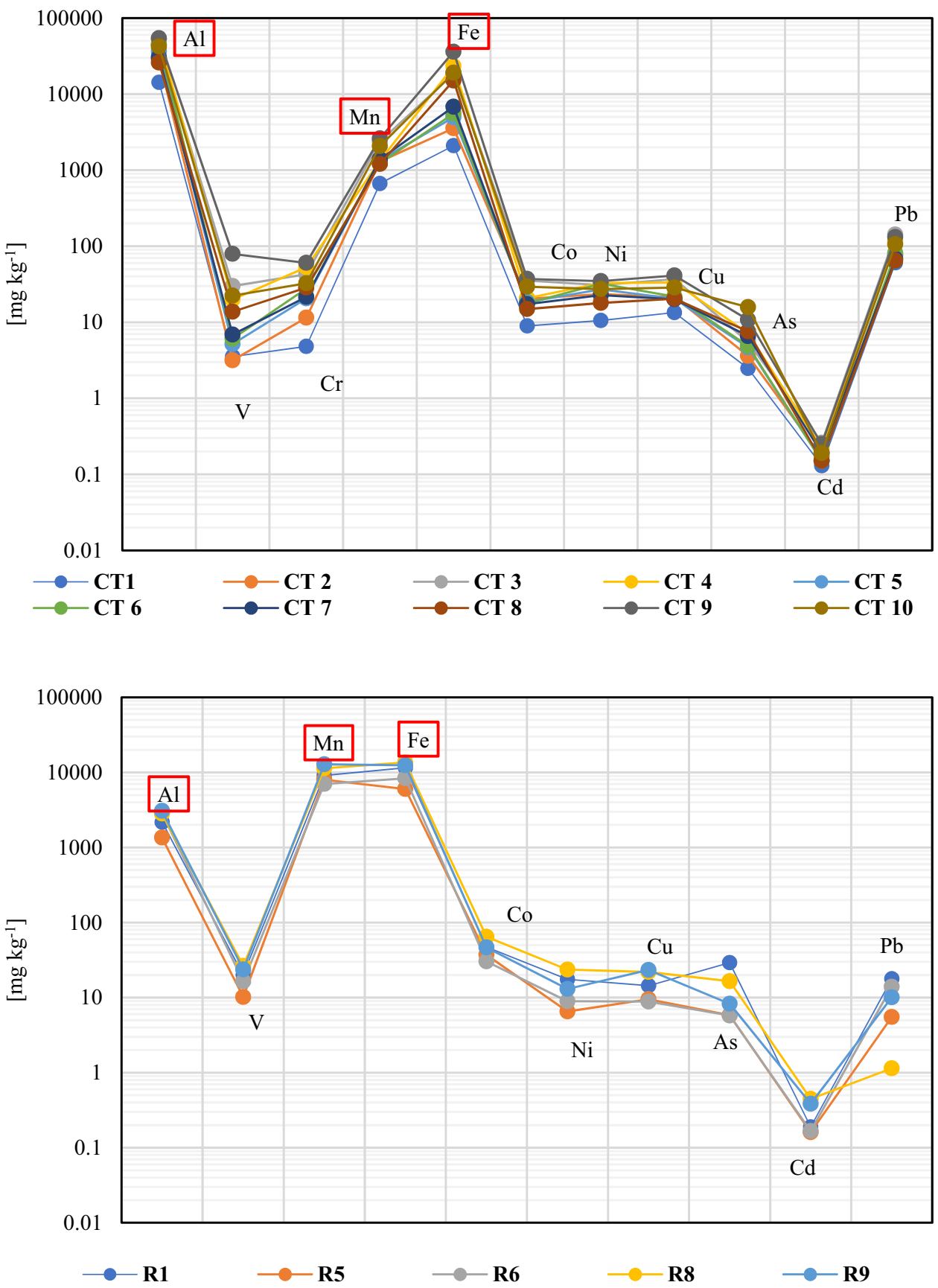

\begin{tabular}{llllllll}
\hline & $I_{\text {geo }} \mathrm{V}$ & $l_{\text {geo }} \mathrm{Cr}$ & $I_{\text {geo }} \mathrm{Ni}$ & $I_{\text {geo }} \mathrm{Cu}$ & $I_{\text {geo }} \mathrm{As}$ & $I_{\text {geo }} \mathrm{Cd}$ & $I_{\text {geo }} \mathrm{Pb}$ \\
\hline Rainer Quarry & -1.122 & -1.696 & -1.731 & -0.974 & -0.391 & -2.330 & -1.931 \\
Femar Quarry & -0.859 & -1.289 & -1.440 & -0.690 & -1.181 & -2.172 & -1.902 \\
\hline
\end{tabular}

Table 1 Geoaccumulation index $\left(I_{\text {geo }}\right)$ for Rainer and Femar Quarry
The aluminum (Al) is chosen as reference element to assess the enrichment factor (EF), because it is a highly conservative element and an important constituent of clay minerals [60]. In order to calculate the geoaccumultaion quarries. In order to distinguish the geogenic enrichment or anthropogenic contamination of trace elements in Rainer and Femar quarries, the enrichment factor (EF) was evaluated (Fig. 9). 
Fig. 9 Enrichment factor (EF) for Rainer and Femar Quarry

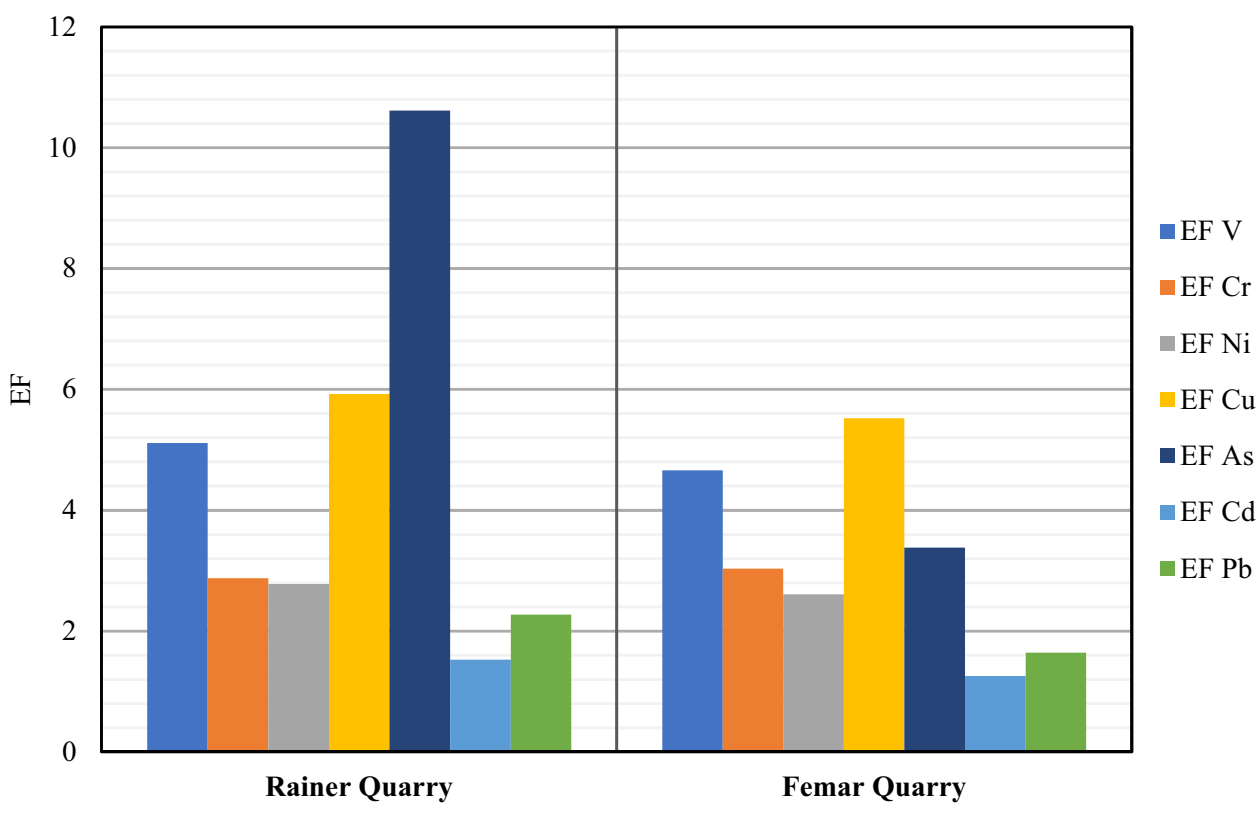

index $\left(I_{\text {geo }}\right)$ and the enrichment factor (EF), the geochemical background concentration of ' $n$ ' trace elements has been considered by "Progetto di Monitoraggio Ambientale su tutto il Territorio della Regione Lombardia-Progetto Soil" [61], equal to the 95th percentile. It is possible to verify that Rainer Quarry is enriched more in Arsenic (As) and Copper $(\mathrm{Cu})$. Other previous studies $[62,63]$ have shown that the significant enrichment of Arsenic in Rainer Quarry is linked to the clayey nature of the soil, with peat lenses, in the study area. This evaluation makes it possible to state that the two sites are not contaminated and, therefore, the trace elements are not linked to anthropogenic inputs, but exclusively to natural enrichment.

\subsection{Case studies in Lazio region}

Samples are assembled at a depth of $1 \mathrm{~m}$ to assess the geoaccumulation index and the enrichment factor and test and differentiate between natural enrichment or anthropic contamination of the trace elements. For studies cases, it was possible to select one background value for all samples, except for the Appian Way Regional Park (one background value every three samples) and Roccasecca (only one background value for all samples) due to the closeness of the samples and the similarity of the features.

Table 2 presents $I_{\text {geo }}$ results for the Appian Way Regional Park, Table 3 shows $I_{\text {geo }}$ values for Borgo Montello soils, Table 4 presents $I_{\text {geo }}$ values for Cisterna di Latina soils and Table 5 presents $I_{\text {geo }}$ values for Roccasecca soils. Alternatively, Fig. 10 shows EF results for the Appian Way Regional Park; Fig. 11 shows EF values for Borgo Montello soils, Fig. 12 shows EF values for Cisterna di Latina soils and Fig. 13 shows EF values for Roccasecca soils.

Tables 2, 3, 4 and 5 show negative $I_{\text {geo }}$ values for each trace elements in almost all samples, showing the absence of anthropogenic enrichment of topsoils. In a few topsoil samples by Appian Way Regional Park (Table 2) and Cisterna di Latina (Table 4), the geoaccumulation index has positive values for some trace elements ( $\mathrm{V}, \mathrm{Cr}, \mathrm{As}, \mathrm{Cd}$ and $\mathrm{Pb}$ ), indicating weak or light
Table 2 Geoaccumulation index $\left(I_{\text {geo }}\right)$ for Appian Way Regional Park

\begin{tabular}{lrrrrrrrr}
\hline & \multicolumn{1}{l}{$I_{\text {geo }} \mathrm{V}$} & \multicolumn{1}{c}{$I_{\text {geo }} \mathrm{Cr}$} & \multicolumn{1}{c}{$I_{\text {geo }} \mathrm{Co}$} & \multicolumn{1}{c}{$I_{\text {geo }} \mathrm{Ni}$} & \multicolumn{1}{c}{$I_{\text {geo }} \mathrm{Cu}$} & \multicolumn{1}{c}{$I_{\text {geo }} \mathrm{As}$} & \multicolumn{1}{c}{$I_{\text {geo }} \mathrm{Cd}$} & \multicolumn{1}{c}{$I_{\text {geo }} \mathrm{Pb}$} \\
\hline $\mathrm{C} 1$ & -0.043 & 0.150 & -0.273 & -0.035 & -0.781 & -0.937 & -1.032 & 0.308 \\
$\mathrm{C} 2$ & 0.027 & 0.320 & -0.340 & -0.062 & -0.837 & -0.927 & -1.215 & 0.592 \\
$\mathrm{C} 3$ & -0.167 & -0.293 & -0.544 & -0.277 & -0.698 & -0.599 & 0.104 & -0.164 \\
$\mathrm{C} 5$ & -0.108 & -0.501 & -0.103 & 0.208 & 0.232 & 0.423 & -0.405 & 0.468 \\
$\mathrm{C} 6$ & -0.289 & -0.385 & -0.435 & -0.205 & -0.475 & -0.368 & -0.641 & -0.701 \\
$\mathrm{C} 7$ & -0.421 & 0.271 & -0.359 & 0.282 & -0.447 & -0.232 & -0.806 & -0.095 \\
$\mathrm{C} 4$ & -0.325 & -0.583 & -0.731 & -0.580 & -0.823 & -0.573 & -0.832 & -0.903 \\
$\mathrm{C} 8$ & -0.268 & -0.025 & -0.339 & -0.099 & -0.427 & -0.529 & -0.458 & -0.076 \\
$\mathrm{C} 12$ & -0.400 & -0.099 & -0.150 & -0.296 & -0.363 & -0.555 & -0.480 & -0.102 \\
\hline
\end{tabular}


Table 3 Geoaccumulation index $\left(I_{\text {geo }}\right)$ for Borgo Montello

\begin{tabular}{lrrrrrrrr}
\hline & \multicolumn{1}{c}{$I_{\text {geo }} \mathrm{V}$} & \multicolumn{1}{c}{$I_{\text {geo }} \mathrm{Cr}$} & \multicolumn{1}{c}{$I_{\text {geo }} \mathrm{Co}$} & \multicolumn{1}{c}{$I_{\text {geo }} \mathrm{Ni}$} & \multicolumn{1}{c}{$I_{\text {geo }} \mathrm{Cu}$} & \multicolumn{1}{c}{$I_{\text {geo }} \mathrm{As}$} & \multicolumn{1}{c}{$I_{\text {geo }} \mathrm{Cd}$} & \multicolumn{1}{c}{$I_{\text {geo }} \mathrm{Pb}$} \\
\hline B1 & 0.065 & -0.526 & -0.340 & -0.630 & -0.231 & -0.461 & -0.715 & -0.627 \\
B2 & -0.320 & -0.176 & -0.507 & -0.358 & -0.404 & -0.400 & -0.350 & -0.504 \\
B3 & -0.041 & 0.298 & -0.398 & -0.306 & -0.900 & 0.415 & -0.128 & -1.120 \\
B4 & 0.039 & 0.041 & 0.093 & -0.262 & -0.602 & -1.029 & 0.323 & -0.909 \\
B5 & 0.436 & -0.284 & 0.518 & -0.015 & 0.249 & 0.501 & 0.468 & 0.468 \\
B6 & -0.213 & -0.282 & -3.319 & -1.431 & -1.349 & -1.516 & -1.099 & -2.112 \\
B7 & 1.069 & 1.250 & -1.073 & 0.411 & -0.572 & -0.131 & 0.457 & -1.309 \\
B8 & 1.031 & 0.804 & -0.864 & 0.158 & -1.438 & -0.864 & -0.301 & -2.739 \\
B9 & -0.326 & 0.422 & -0.677 & -0.234 & -2.535 & -1.374 & -2.878 & -1.697 \\
B10 & -1.143 & -0.661 & -1.832 & -0.073 & -2.232 & -0.771 & -1.720 & -1.875 \\
B11 & -0.777 & -0.636 & -1.511 & -0.423 & -1.762 & -0.300 & -2.076 & -1.891 \\
B12 & 0.607 & 1.604 & -0.447 & 0.437 & -1.913 & -0.602 & -1.385 & -2.077 \\
B13 & 0.612 & 1.166 & 0.882 & 0.612 & 0.905 & -0.300 & 0.235 & -0.783 \\
B14 & -1.282 & -1.242 & -1.298 & -0.683 & -2.607 & -0.482 & -3.412 & -2.314 \\
B15 & 1.054 & 0.999 & 0.123 & 0.147 & 0.594 & 0.228 & 1.191 & -0.808 \\
B16 & -1.132 & 0.224 & -1.108 & 0.074 & -2.259 & -0.130 & -2.426 & -2.978 \\
\hline
\end{tabular}

\begin{tabular}{lrrrrrrrr}
\hline & \multicolumn{1}{l}{$I_{\text {geo }} \mathrm{V}$} & \multicolumn{1}{c}{$I_{\text {geo }} \mathrm{Cr}$} & \multicolumn{1}{c}{$I_{\text {geo }} \mathrm{Co}$} & \multicolumn{1}{c}{$I_{\text {geo }} \mathrm{Ni}$} & \multicolumn{1}{c}{$I_{\text {geo }} \mathrm{Cu}$} & $I_{\text {geo }} \mathrm{As}$ & $I_{\text {geo }} \mathrm{Cd}$ & $I_{\text {geo }} \mathrm{Pb}$ \\
\hline CT1 & -1.659 & -1.398 & -0.449 & -0.593 & -0.460 & -0.844 & -0.038 & -0.068 \\
CT 2 & -2.633 & -1.388 & -0.673 & -0.587 & -1.292 & -0.982 & -0.708 & -0.842 \\
CT 3 & 0.394 & -0.087 & -0.280 & -0.424 & -0.343 & -0.427 & -0.325 & -0.243 \\
CT 4 & 0.340 & 0.489 & -0.011 & -0.297 & 0.221 & -0.242 & 0.047 & -0.035 \\
CT 5 & -0.786 & -0.839 & 0.030 & -0.615 & -0.446 & -0.141 & 0.223 & -0.382 \\
CT 6 & -0.372 & -0.225 & -0.279 & -0.314 & -0.266 & -0.503 & -0.182 & -0.259 \\
CT 7 & -1.271 & -0.845 & -0.814 & -0.682 & -0.689 & -0.785 & -0.552 & -0.662 \\
CT 8 & -0.359 & -0.363 & -0.591 & -0.815 & -0.585 & -0.337 & -0.336 & -0.688 \\
CT 9 & -0.643 & -0.471 & -0.412 & -0.586 & -0.561 & -2.909 & -0.554 & -0.244 \\
CT 10 & -0.082 & 0.018 & 0.240 & 0.020 & 0.030 & -0.169 & -0.100 & 0.100 \\
\hline
\end{tabular}

Table 4 Geoaccumulation index $\left(I_{\text {geo }}\right)$ for Cisterna di Latina
Table 5 Geoaccumulation index $\left(I_{\text {geo }}\right)$ for Roccasecca

\begin{tabular}{lrrrrrrr}
\hline & \multicolumn{1}{c}{$I_{\text {geo }} \mathrm{V}$} & \multicolumn{1}{c}{$I_{\text {geo }} \mathrm{Co}$} & \multicolumn{1}{c}{$I_{\text {geo }} \mathrm{Ni}$} & \multicolumn{1}{c}{$I_{\text {geo }} \mathrm{Cu}$} & $I_{\text {geo }} \mathrm{As}$ & \multicolumn{1}{c}{$I_{\text {geo }} \mathrm{Cd}$} & \multicolumn{1}{c}{$I_{\text {geo }} \mathrm{Pb}$} \\
\hline R1 & -0.199 & -0.267 & -0.532 & -0.234 & 1.707 & -0.207 & 0.076 \\
R5 & -0.876 & -0.505 & -1.522 & -0.649 & 0.097 & -0.367 & -1.096 \\
R6 & -0.396 & -0.706 & -1.207 & -0.722 & 0.087 & -0.331 & -0.166 \\
R8 & 0.077 & 0.049 & -0.236 & 0.185 & 1.137 & 0.651 & -2.671 \\
R9 & -0.031 & -0.280 & -0.829 & 0.247 & 0.447 & 0.502 & -0.493 \\
\hline
\end{tabular}

enrichment. Instead, in some topsoil samples by Borgo Montello (B7, B8, B12, B13 and B15-Table 3) and Roccasecca (R1 and R8-Table 4), there are $I_{\text {geo }}$ values between 1 and 2 for some trace elements ( $\mathrm{ss}, \mathrm{V}, \mathrm{Cr}, \mathrm{Cd}, \mathrm{Co}$ ) that indicate moderate conditions of contamination. This could be linked to the proximity of the Borgo Montello and Roccasecca to a municipal solid waste landfill and a waste treatment plant. The wastes with trace elements such as V, As, Cr, Cd and Co are transported to landfills daily and they may be carried to the soil by wind and may, therefore, be subject to atmospheric deposition. The calculation of the enrichment factor confirms the results defined for these case studies (Figs. 10, 11, 12, 13). The aluminum (Al) is chosen as a reference element to assess the enrichment factor (EF), because it is a highly conservative element and an essential constituent of clay minerals [60]. Boxplots were used to show the results of the enrichment factor (Figs. 10, 11, 12, 13), in order to represent the statistical distribution synthetically, using lighter and darker colors to highlight 
Fig. 10 Enrichment factor (EF) for Appian Way Regional Park
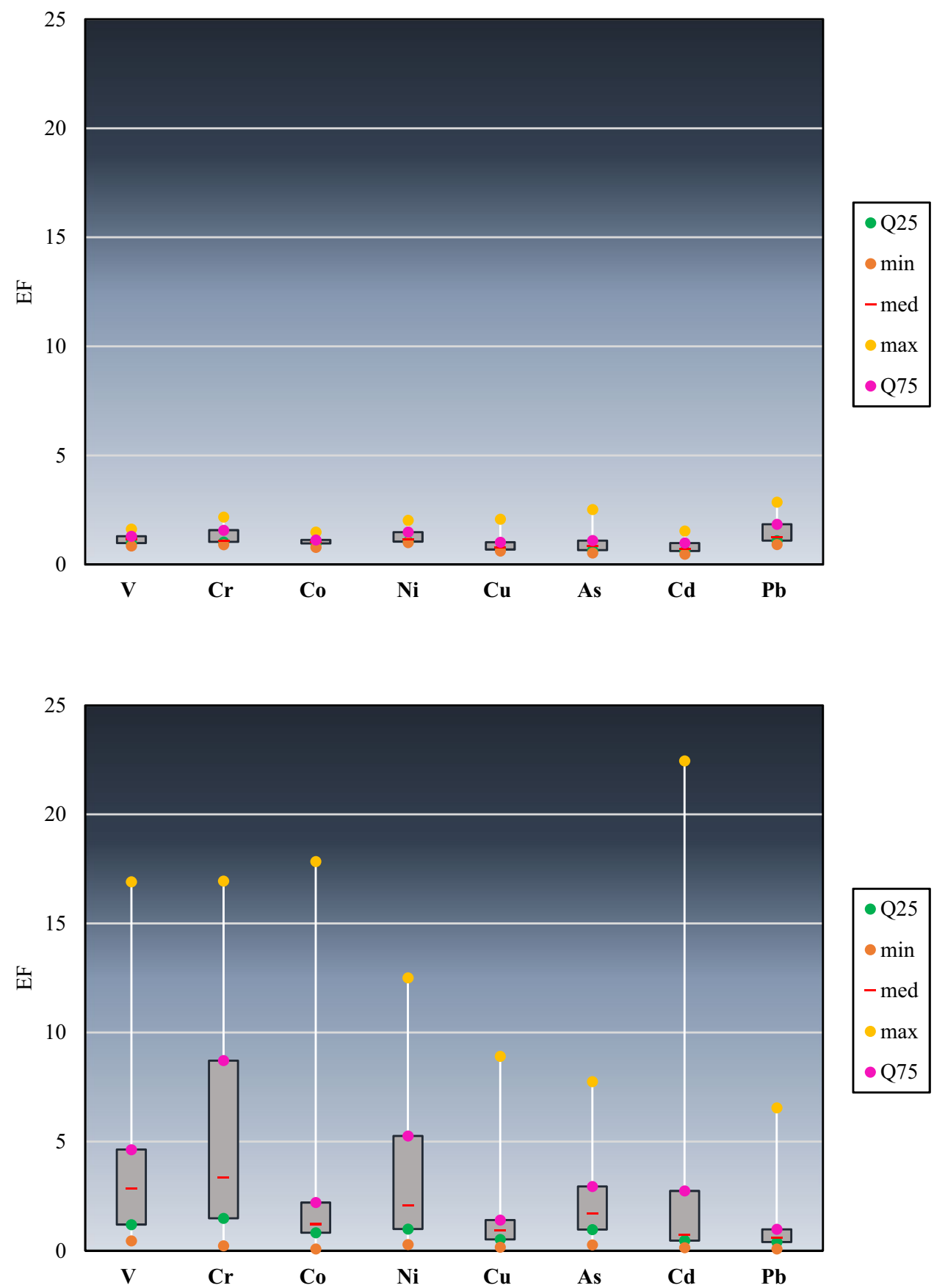

Fig. 11 Enrichment factor (EF) for Borgo Montello the increase in the enrichment factor. Borgo Montello (Fig. 11) is characterized by high values of the enrichment factor, with amounts almost equal to 25 for the $\mathrm{Cd}$, thus confirming anthropic contamination. The enrichment factor results for the Roccasecca (Fig. 13) also confirm significant values, especially for the As, probably linked to the presence of municipal solid waste landfill. Instead, for Appian Way Regional Park (Fig. 10) and Cisterna di Latina (Fig. 12), there are enrichment factor values less than 5 , highlighting a moderate enrichment in trace elements, probably associated with the geogenic nature of the soils.

\subsubsection{Assessment of geochemical baseline values in Borgo Montello}

According to Zhou et al. [29], the statistical approach is applied to Borgo Montello case study. Borgo Montello is the case study in Lazio region with the greatest number of data, with concentrations above the threshold values 
Fig. 12 Enrichment factor (EF) for Cisterna di Latina
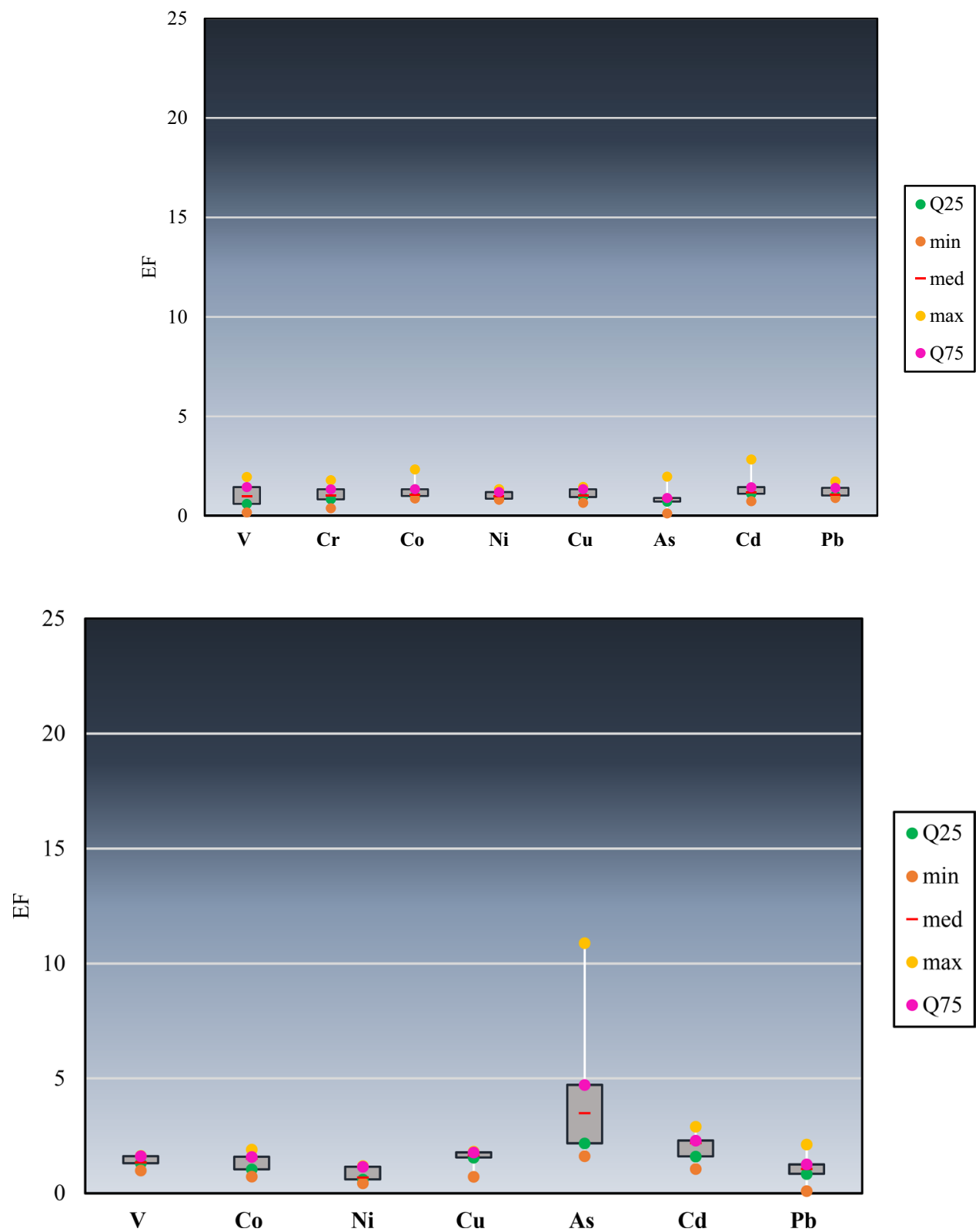

Fig. 13 Enrichment factor (EF) for Roccasecca of the Italian Legislative Decree 152/2006. The results provided by the statistical approach are incomplete, due to the small number of samples available (16 surface sediment samples), but it may be useful for subsequent processing with more topsoil samples. The Pearson correlation matrix (Table 6) is used to determine the relationship between trace elements.

The statistical approach is characterized by two steps:

1. Processing of the cumulative frequency curve (CFD) for the trace element whose geochemical baseline value is to be checked;

2. Normalization (a linear regression) through the expressions 1 and 2 between two elements: the trace ele- ment and a reference element present significantly in the soils. A conservative reference element is chosen because it is not affected by anthropogenic inputs and its high behavior is linked to geogenic enrichment of the soils.

For Borgo Montello, manganese is chosen as reference element, because it is present with high amount in soils $[46,47]$.The statistical approach was applied to vanadium, chromium, cobalt and nickel to define geochemical baseline values, because significant correlations between manganese and the trace elements are highlighted by the Pearson matrix (Table 6). This results from the biological and geochemical properties of this element and from the 


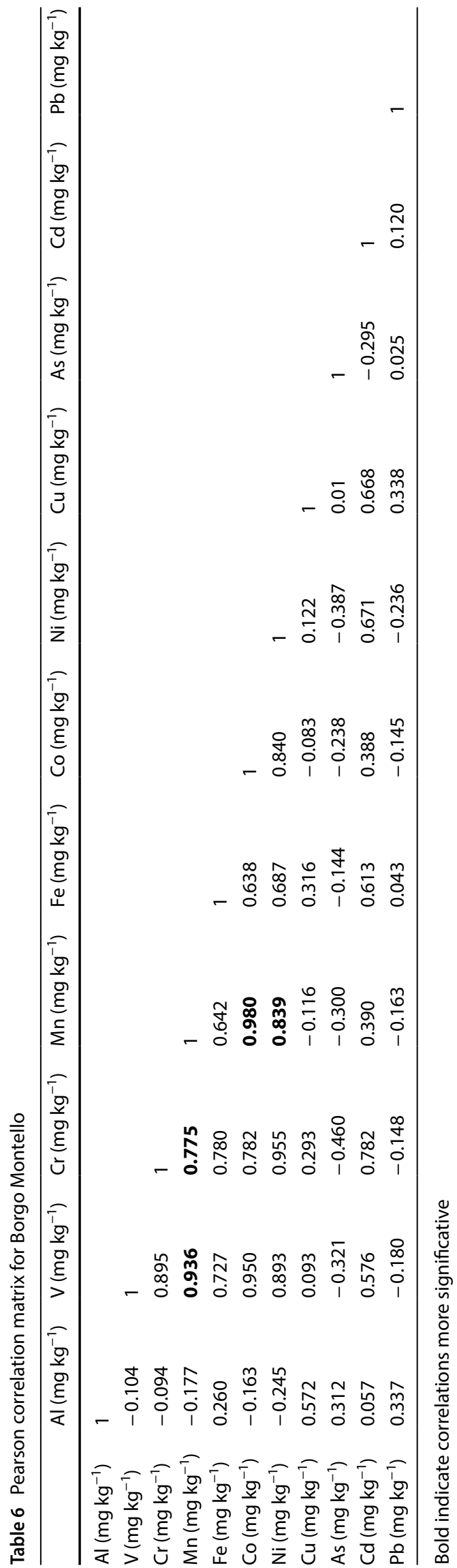

fact that in soils chromium is bound mainly by the organic compound.

In this study, the arithmetic mean of $\mathrm{V}$ is $142.34 \mathrm{mg} \mathrm{kg}^{-1}$, $\mathrm{Cr}$ is $105.46 \mathrm{mg} \mathrm{kg}^{-1}$, Co is $12.97 \mathrm{mg} \mathrm{kg}^{-1}$ and $\mathrm{Ni}$ is $31.2 \mathrm{mg} \mathrm{kg}^{-1}$. Therefore, the cumulative frequency curve method is applied to V (Fig. 14a), Cr (Fig. 14b), Co (Fig. 14c) and has $\mathrm{Ni}$ (Fig. 14d): their curve has one inflexion.

Thus, the geochemical baseline for $\mathrm{V}, \mathrm{Cr}, \mathrm{Co}$ and $\mathrm{Ni}$ was obtained from the data below the inflexion value, considering the arithmetic mean of the remaining values. The calculated baseline concentration of $\mathrm{V}$ is $78.24 \mathrm{mg} \mathrm{kg}^{-1}, \mathrm{Cr}$ is $84.10 \mathrm{mg} \mathrm{kg}^{-1}$, Co is $6.67 \mathrm{mg} \mathrm{kg}^{-1}$ and $\mathrm{Ni}$ is $23.7 \mathrm{mg} \mathrm{kg}^{-1}$. For normalization method (Fig. 15), Mn is selected as the reference element.

The correlation coefficients increase after points falling out of the $95 \%$ confidence band are removed. The remaining data points were used to calculate the geochemical baseline as follows:

$B_{\mathrm{V}}=-0.1469 * \overline{\mathrm{Mn}}+178.92, r=0.83$

$B_{\mathrm{Cr}}=-0.042 * \overline{\mathrm{Mn}}+99.294, r=0.88$

$B_{\mathrm{Co}_{0}}=0.0418 * \overline{\mathrm{Mn}}-6.68, r=0.97$

$B_{\mathrm{Ni}}=-0.0549 * \overline{\mathrm{Mn}}+50.58, r=0.81$

The calculated geochemical baseline value of $\mathrm{V}$ is $123.07 \mathrm{mg} \mathrm{kg}^{-1}$, greater than the result obtained by cumulative frequency curve method $\left(78.24 \mathrm{mg} \mathrm{kg}^{-1}\right), \mathrm{Cr}$ is $82.10 \mathrm{mg} \mathrm{kg}^{-1}$, similar to the value obtained using the cumulative frequency curve method $\left(84.10 \mathrm{mg} \mathrm{kg}^{-1}\right)$, Co is $9.41 \mathrm{mg} \mathrm{kg}^{-1}$ and $\mathrm{Ni}$ is $29.70 \mathrm{mg} \mathrm{kg}^{-1}$, both quite similar to values obtained using cumulative frequency curve method (respectively for Co is $6.67 \mathrm{mg} \mathrm{kg}^{-1}$ and $\mathrm{Ni}$ is $23.7 \mathrm{mg} \mathrm{kg}^{-1}$ ). The number of topsoil samples available is too small to make a more correct estimate, in fact according to Zhou et al. [29] the number of topsoil samples used it is approximately 40 . It is however possible to verify that the chromium, cobalt and nickel geochemical baseline values established using both the cumulative frequency method and the normalization method are similar. Instead, the calculation of vanadium geochemical baseline values through statistical approach determines irregular values.

\section{Conclusions}

The article proposes a procedure to determine the origin of trace elements in topsoil, in order to distinguish natural enrichment, due to parent material and geogenic origin, and anthropogenic contamination, caused by activities 


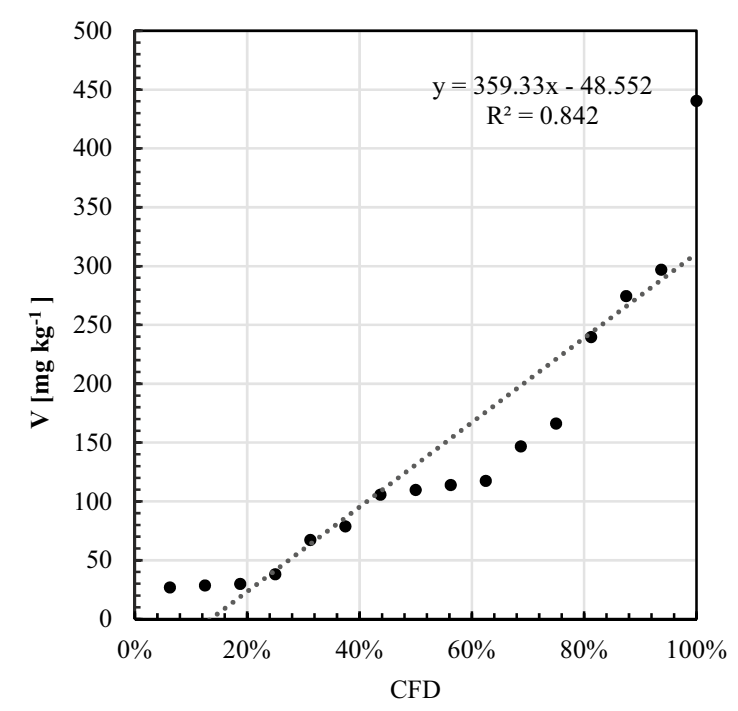

(a)

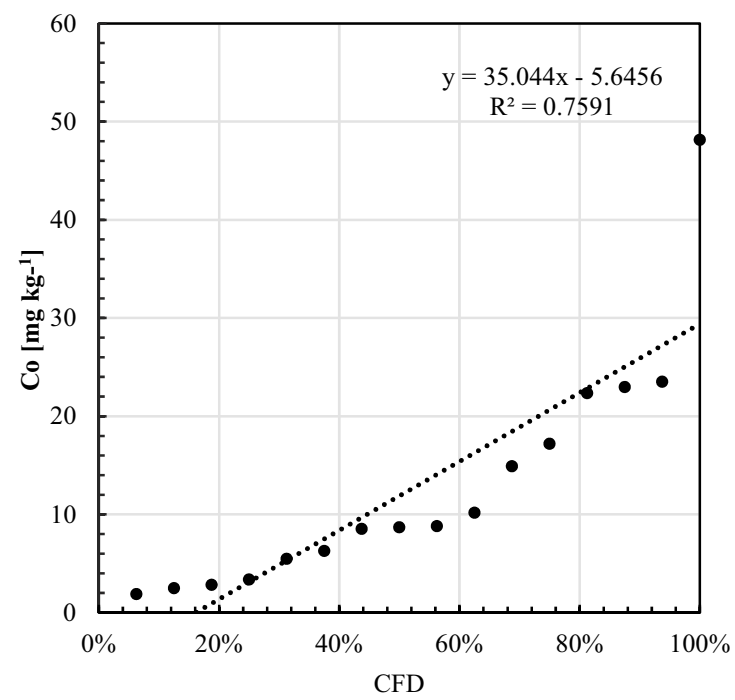

(c)

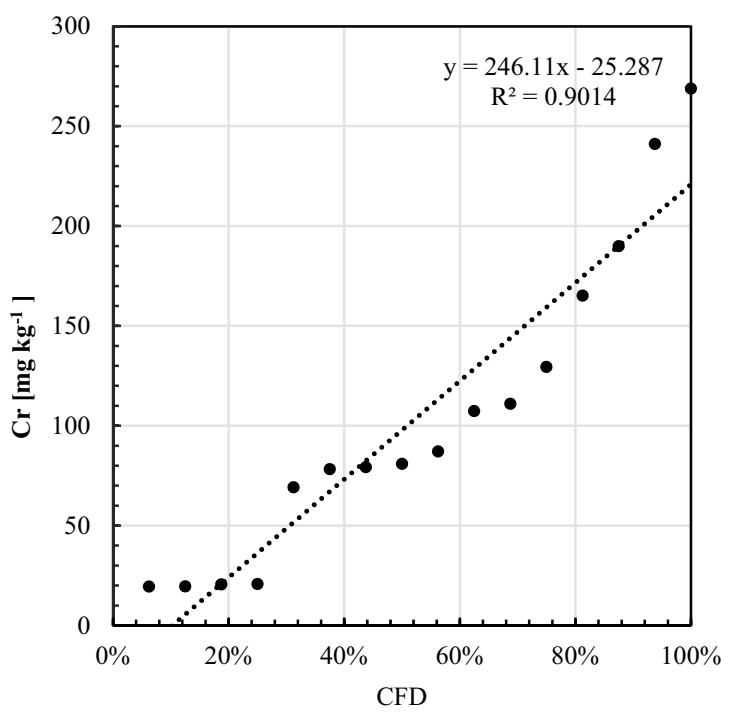

(b)

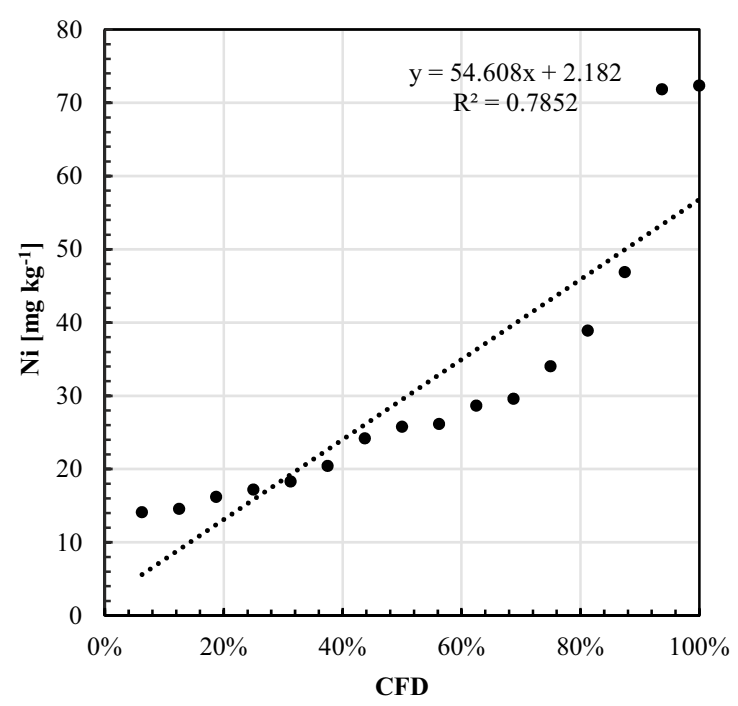

(d)

Fig. 14 Cumulative frequency curve method for vanadium (a), chromium (b), cobalt (c) and nickel (d) in Borgo Montello

such as presence of landfills, municipal solid waste plants, industrial areas, non-operative quarries, etc. In order to verify the origin of the trace elements in the soils, the procedure highlights the need to distinguish between the total fraction and the exchangeable fraction of the trace elements in the soils. In fact, the exchangeable fraction identifies the rate of an element adsorbed on the main constituents of the soil (clayey material, iron oxides or hydroxides, organic material) and environmentally it represents the bioavailable quote of the trace elements can enter in contact with environment (soil or groundwater) and with food chains, thus causing actual pollution phenomena. The proposed procedure also highlights the need to determine the local geochemical baseline values in order to assess the soil pollution status. In the hypothesis of absence of a Regional Geochemical Baseline Mapping or of the impossibility of subsurface soil horizion sampling at a maximum depth of one meter, a statistical method is considered to assess the geochemical baseline. Furthermore, it is essential to consider some pollution indicators that allow to verify the possible origin of trace elements in the soils. In fact, the proposed procedure involves the 


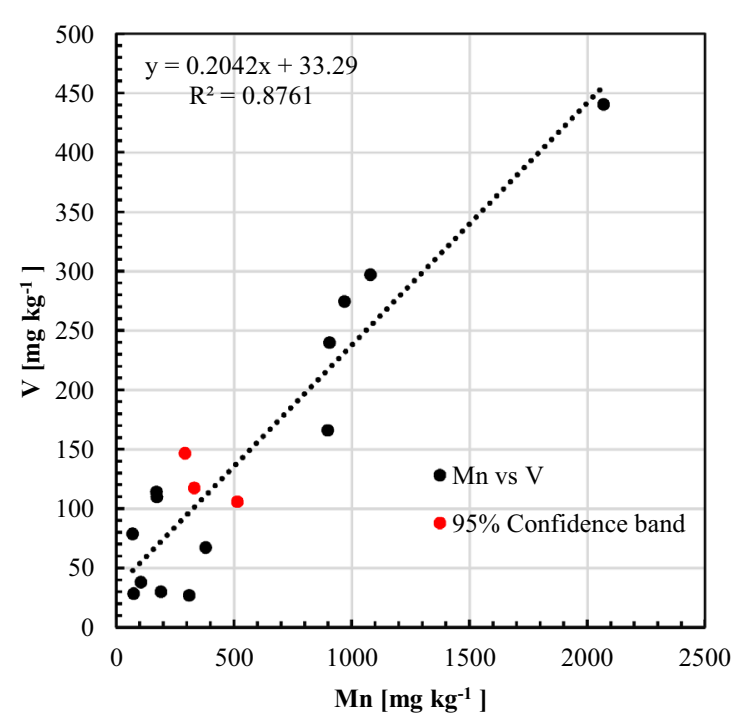

(a)

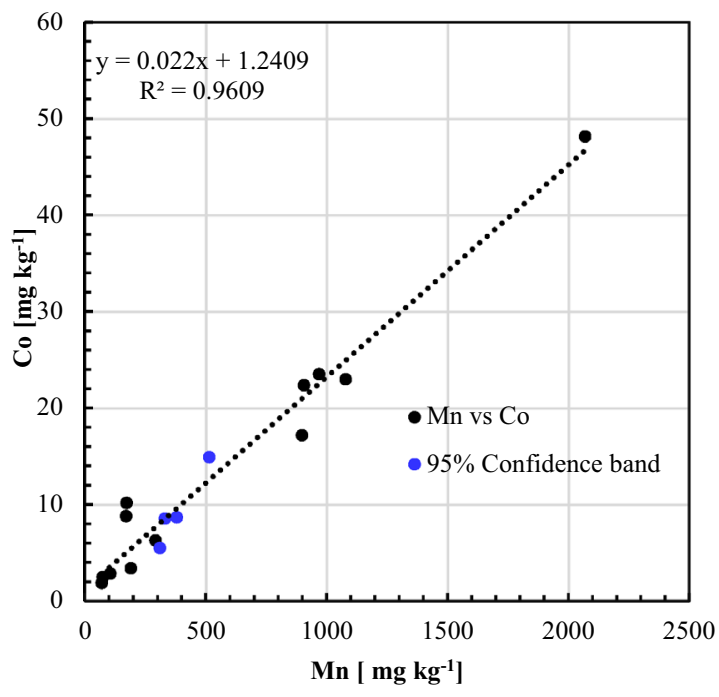

(c)

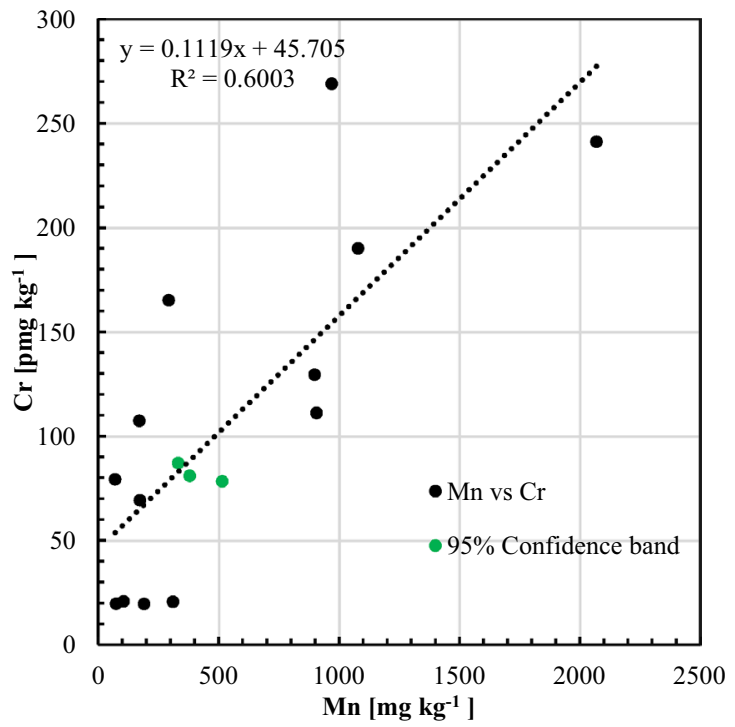

(b)

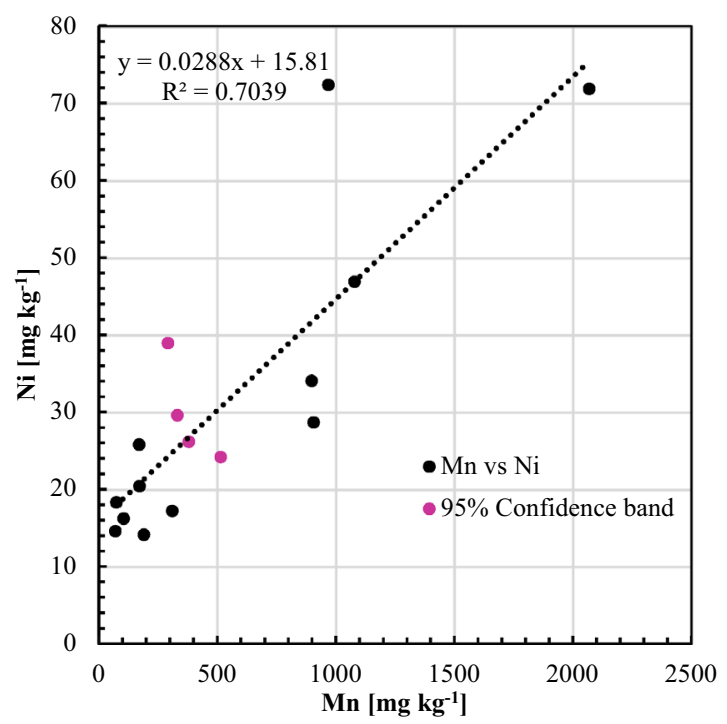

(d)

Fig. 15 Normalization method between manganese and vanadium (a), manganese and chromium (b), manganese e cobalt (c), manganese e nickel (d) in Borgo Montello

definition of the geoaccumulation index $\left(I_{\text {geo }}\right)$ and the determination of the enrichment factor (EF). These indices have been applied to several Italian case studies with the aim to verify the origin of the trace elements, if the concentrations are above the threshold values of the Italian Legislative Decree 152/06. In the case of Bevera Valley Basin in Lombardy, the geoaccumulation index and the enrichment factor allowed to verify the absence of anthropogenic contamination, but an arsenic geogenic enrichment in Femar and Reinar querries due to peat lenses in the study area. However, for the case studies in the lower Lazio region, in the Borgo Montello and Roccasecca sites, contamination is plausibly associated with the presence municipal solid waste landfill and a waste treatment plant. On the contrary, for the cases of the Appian Way Regional Park and Cisterna di Latina, a natural enrichment of the soils is confirmed due to the geogenic origin. Moreover, the statistical approach to assess the geochemical baseline values was applied to Borgo Montello case study. The results highlight the need to have a high number of topsoil 
samples and homogeneously located in the study area. Although the small amount of data available for Borgo Montello, it is possible to verify for chromium, cobalt and nickel a good correlation between the geochemical baseline value obtained by the cumulative frequency method and the normalization method with manganese. The result highlights also the biological and geochemical properties of this element and from the fact that in soils chromium is bound mainly by the organic compound.

Acknowledgements Open access funding provided by Università degli Studi di Roma La Sapienza within the CRUI-CARE Agreement.

\section{Compliance with ethical standards}

Conflict of interest On behalf of all authors, the corresponding author states that there is no conflict of interest.

Open Access This article is licensed under a Creative Commons Attribution 4.0 International License, which permits use, sharing, adaptation, distribution and reproduction in any medium or format, as long as you give appropriate credit to the original author(s) and the source, provide a link to the Creative Commons licence, and indicate if changes were made. The images or other third party material in this article are included in the article's Creative Commons licence, unless indicated otherwise in a credit line to the material. If material is not included in the article's Creative Commons licence and your intended use is not permitted by statutory regulation or exceeds the permitted use, you will need to obtain permission directly from the copyright holder. To view a copy of this licence, visit http://creativecommons .org/licenses/by/4.0/.

\section{References}

1. Chen HM, Zheng CR, Tu C, Zhou DM (2001) Studies on loading capacity of agricultural soils for heavy metals and its applications in China. Appl. Sci. 16:1397-1403. https://doi.org/10.1016/ S0883-2927(01)00041-5

2. Galán E, Romero-Baena AJ, Aparicio P, González I (2019) A methodological approach for the evaluation of soil pollution by potentially toxic trace elements. J Geochem Explor 203:96-107. https://doi.org/10.1016/j.gexplo.2019.04.005

3. Wuana RA, Okieimen FE (2011) Heavy metals in contaminated soils: a review of sources, chemistry, risks and best available strategies for remediation. ISRN Ecol 402647:20. https://doi. org/10.5402/2011/402647

4. Alloway BJ (1995) Heavy metals in soils. Blackie Academic and Professional, London

5. Leung HM, Leung AOW, Wang HS, Ma KK, Liang Y, Ho KC, Cheung KC, Tohidi F, Yung KKL (2014) Assessment of heavy metals/metalloid ( $\mathrm{As}, \mathrm{Pb}, \mathrm{Cd}, \mathrm{Ni}, \mathrm{Zn}, \mathrm{Cr}, \mathrm{Cu}, \mathrm{Mn}$ ) concentrations in edible fish species tissue in the Pearl river delta (PRD), China. Mar Pollut Bull 78:235-245

6. Wang J, Liu R, Zhang P, Yu W, Shen Z, Feng C (2014) Spatial variation, environmental assessment and source identification of heavy metals in sediments of the Yangtze River Estuary. Mar Pollut Bull 87:364-373

7. Plumlee $\mathrm{G}$ (1994) Environmental geology models of mineral deposits. SEG NewsI 16:5-6
8. Ludden J, Peach D, Flight D (2015) Geochemically based solutions for urban society: London, a case study. Elements 11:253258. https://doi.org/10.2113/gselements.11.4.253

9. Hu Y, Cheng H (2013) Application of stochastic models in identification and apportionment of heavy metal pollution sources in the surface soils of a large-scale region. Environ Sci Technol 47:3752-3760. https://doi.org/10.1021/es304310k

10. Zheng S, Wang P, Wang C, Hou J, Qian J (2013) Distribution of metals in water and suspended particulate matter during the resuspension processes in Taihu Lake sediment, China. Quatern Int 286:94-102. https://doi.org/10.1016/j.quaint.2012.09.003

11. Fu J, Zhao C, Luo Y, Liu C, Kyzas GZ, Luo Y, Zhao D, An S, Zhu $H$ (2014) Heavy metals in surface sediments of the Jialu River, China: their relations to environmental factors. J Hazard Mater 270:102-109. https://doi.org/10.1016/j.jhazmat.2014.01.044

12. McLaughlin MJ, Zarcinas BA, Stevens DP, Cook N (2000) Soil testing for heavy metals. Commun Soil Sci Plan 31:1661-1700

13. Santos-Francés F, Martínez-Graña A, Alonso Rojo P, García Sánchez A (2017) Geochemical background and baseline values determination and spatial distribution of heavy metal pollution in soils of the Andes mountain range (CajamarcaHuancavelica, Peru). Int J Environ Res Public Health 14:859. https://doi.org/10.3390/ijerph14080859

14. Basta NT, Ryan JA, Chaney RL (2005) Trace element chemistry in residual-treated soil. J Environ Qual 34:49-63. https://doi. org/10.2134/jeq2005.0049dup

15. Petrik A, Thiombane M, Lima A, Albanese S, Buscher JT, De Vivo B (2018) Soil contamination compositional index: a new approach to quantify contamination demonstrated by assessing compositional source patterns of potentially toxic elements in the Campania Region (Italy). J Appl Geochem 96:264-276. https://doi.org/10.1016/j.apgeo chem.2018.07.014

16. Barbieri $M(2016)$ The importance of enrichment factor (EF) and geoaccumulation index (Igeo) to evaluate the soil contamination. J Geol Geophys 5:1-4. https://doi.org/10.4172/23818719.1000237

17. Salminen R, Gregorauskien V (2000) Considerations regarding the definition of a geochemical baseline of elements in the surficial materials in areas differing in basic geology. J Appl Geochem 15:647-653. https://doi.org/10.1016/S0883-2927(99)00077-3

18. Dişli E, Gülyüz N (2020) Hydrogeochemical investigation of an epithermal mineralization bearing basin using multivariate statistical techniques and isotopic evidence of groundwater: Kestanelik Sub-Basin, Lapseki, Turkey. Geochemistry. https:// doi.org/10.1016/j.chemer.2020.125661

19. Plant J, Smith D, Smith B, Williams L (2001) Environmental geochemistry at the global scale. Appl Geochem 16:1291-1308. https://doi.org/10.1016/S0883-2927(01)00036-1

20. García-Sánchez A, Alonso-Rojo P, Santos-Francés F (2010) Distribution and mobility of arsenic in soils of a mining area (Western Spain). Sci Total Environ 408:4194-4201. https://doi. org/10.1016/j.scitotenv.2010.05.032

21. Reimann C, Garrett RG (2005) Geochemical backgroundconcept and reality. Sci. Total Envi. 350:12-27. https://doi. org/10.1016/j.scitotenv.2005.01.047

22. Kabata-Pendias A, Pendias H (2001) Trace elements in soils and plants. CRC Press, Boca Raton, p 403

23. Cicchella D, De Vivo B, Lima A (2005) Background and baseline concentration values of elements harmful to human health in the volcanic soils of the metropolitan and provincial areas of Napoli (Italy). Geochem Explor Environ Anal 5:29-40. https:// doi.org/10.1144/1467-7873/03-042

24. Albanese S, De Vivo B, Lima A, Cicchella D (2007) Geochemical background and baseline values of toxic elements in stream 
sediments of Campania region (Italy). J Geochem Explor 93:2134. https://doi.org/10.1016/j.gexplo.2006.07.006

25. Wei C, Wen H (2012) Geochemical baselines of heavy metals in the sediments of two large freshwater lakes in China: implications for contamination character and history. Environ Geochem Health 34:737-748. https://doi.org/10.1007/s10653-012-9492-9

26. Rojo PA, Frances FS, Garcia-Sanchez A, Alvarez-Ayuso E (2004) Baseline concentrations of heavy metals in native soils of the Salamanca and Valladolid provinces, Spain. Arid Land Res Manag. 18:241-250. https://doi.org/10.1080/153249804904513 20

27. Sawe SF, Shilla DA, Machiwa JF (2019) Assessment of enrichment, geo-accumulation and ecological risk of heavy metals in surface sediments of the Msimbazi mangrove ecosystem, coast of Dar es Salaam, Tanzania. J Chem Ecol 35:835-845. https://doi. org/10.1080/02757540.2019.1663344

28. Li Z, Deblon J, Zu Y, Colinet G, Li B, He Y (2019) Geochemical baseline values determination and evaluation of heavy metal contamination in soils of Lanping Mining Valley (Yunnan Province, China). Int J Environ Res Public Health 16:4686

29. Zhou Y, Gao L, Xu D, Gao B (2019) Geochemical baseline establishment, environmental impact and health risk assessment of vanadium in lake sediments, China. Sci Total Environ 660:13381345. https://doi.org/10.1016/j.scitotenv.2019.01.093

30. Petrosyan V, Pirumyan G, Perikhanyan Y (2019) Determination of heavy metal background concentration in bottom sediment and risk assessment of sediment pollution by heavy metals in the Hrazdan River (Armenia). Appl Water Sci 9:102. https://doi. org/10.1007/s13201-019-0996-7

31. Niu S, Gao L, Wang X (2019) Characterization of contamination levels of heavy metals in agricultural soils using geochemical baseline concentrations. J Soil Sediment 19:1697-1707. https ://doi.org/10.1007/s11368-018-2190-1

32. Gowd SS, Reddy MR, Govil PK (2010) Assessment of heavy metal contamination in soils at Jajmau (Kanpur) and Unnao industrial areas of the Ganga Plain, Uttar Pradesh, India. J Hazard Mater 174:113-121. https://doi.org/10.1016/j.jhazmat.2009.09.024

33. Mummullage S, Egodawatta P, Ayoko GA, Goonetilleke A (2016) Use of physicochemical signatures to assess the sources of metals in urban road dust. Sci Total Environ 541:1303-1309. https:// doi.org/10.1016/j.scitotenv.2015.10.032

34. Zhang Z, Juying L, Mamat Z, QingFu Y (2016) Sources identification and pollution evaluation of heavy metals in the surface sediments of Bortala River, Northwest China. Ecotoxicol Environ Saf 126:94-101. https://doi.org/10.1016/j.ecoenv.2015.12.025

35. Huang SH, Yang Y, Yuan CY, Li Q, Ouyang K, Wang B, Wang ZX (2017) Pollution evaluation of heavy metals in soil near smelting area by index of geoaccumulation (Igeo). In: IOP conference series: earth and environmental science, vol 52. https://doi. org/10.1088/1755-1315/52/1/012095

36. Barbieri M, Sappa G, Nigro A (2018) Soil pollution: anthropogenic versus geogenic contributions over large areas of the Lazio region. J Geochem Explor 195:78-86. https://doi. org/10.1016/j.gexplo.2017.11.014

37. Tessier A, Campbell PG, Bisson M (1979) Sequential extraction procedure for the speciation of particulate trace metals. Anal Chem 51:844-851

38. Frankowski M, Zioła-Frankowska A, Kowalski A, Siepak J (2010) Fractionation of heavy metals in bottom sediments using Tessier procedure. Environ Earth Sci 60:1165-1178. https://doi. org/10.1007/s12665-009-0258-3

39. Chapman PM (2007) Determining when contamination is pollution - weight of evidence determinations for sediments and effluents. Environ Int 33:492-501. https://doi.org/10.1016/j. envint.2006.09.001
40. Newman MC, Jagoe CH (1994) Inorganic toxicants-ligands and the bioavailability of metals in aquatic environments. In: Hameling JL, Landrum PF, Bergman HL, Benson WH (eds) Bioavailability: physical, chemical, and biological interactions. CRC Press, Boca Raton, pp 39-91

41. ISPRA (2018) Linee Guida per la determinazione dei valori di fondo per i suoli e per le acque sotterranee

42. EPA (1992) Preparation of soil sampling protocols: sampling techniques and strategies. Office of Research and Development, Washington, p 20460

43. Rao CRM, Sahuquillo A, Sanchez JL (2008) A review of the different methods applied in environmental geochemistry for single and sequential extraction of trace elements in soils and related materials. Water Air Soil Pollut 189:291-333. https://doi. org/10.1007/s11270-007-9564-0

44. Anjos C, Magalhães MCF, Abreu MM (2012) Metal (Al, Mn, Pb and $\mathrm{Zn}$ ) soils extractable reagents for available fraction assessment: comparison using plants, and dry and moist soils from the Braçal abandoned lead mine area, Portugal. J Geochem Explor 113:45-55. https://doi.org/10.1016/j.gexplo.2011.07.004

45. Pinto E, Almeida AA, Ferreira IM (2015) Assessment of metal(loid) s phytoavailability in intensive agricultural soils by the application of single extractions to rhizosphere soil. Ecotoxicol Environ Saf 113:418-424. https://doi.org/10.1016/j.ecoenv.2014.12.026

46. Reimann C, Caritat PD (2000) Intrinsic flaws of element enrichment factors (EFs) in environmental geochemistry. Environ Sci Technol 34:5084-5509. https://doi.org/10.1021/es001339o

47. Yongming H, Peixuan D, Junji C, Posmentier ES (2006) Multivariate analysis of heavy metal contamination in urban dusts of Xi'an, Central China. Sci Total Environ 355:176-186. https:// doi.org/10.1016/j.scitotenv.2005.02.026

48. Loska K, Wiechuła D, Korus I (2004) Metal contamination of farming soils affected by industry. Environ Int 30:159-165. https:// doi.org/10.1016/S0160-4120(03)00157-0

49. Lee CSL, Li X, Shi W, Cheung SCN, Thornton I (2006) Metal contamination in urban, suburban, and country park soils of Hong Kong: a study based on GIS and multivariate statistics. Sci Total Environ 356:45-61. https://doi.org/10.1016/j.scito tenv.2005.03.024

50. Modabberi S, Tashakor M, Soltani NS, Hursthouse AS (2018) Potentially toxic elements in urban soils: source apportionment and contamination assessment. Environ Monit Assess 190:715. https://doi.org/10.1007/s10661-018-7066-8

51. Muller G (1969) Index of geoaccumulation in sediments of the Rhine River. GeoJournal 2:108-118

52. Micó C, Recatalá L, Peris M, Sánchez J (2006) Assessing heavy metal sources in agricultural soils of an European Mediterranean area by multivariate analysis. Chemosphere 65:863-872. https ://doi.org/10.1016/j.chemosphere.2006.03.016

53. Cheng H, Li M, Zhao C, Li K, Peng M, Qin A, Cheng X (2014) Overview of trace metals in the urban soil of 31 metropolises in China. J Geochem Explor 139:31-52. https://doi.org/10.1016/j. gexplo.2013.08.012

54. Chen H, Teng Y, Lu S, Wang Y, Wang J (2015) Contamination features and health risk of soil heavy metals in China. Sci Total Environ 512:143-153. https://doi.org/10.1016/j.scito tenv.2015.01.025

55. Muller G (1981) Schwermetallbelstung der sedimente des neckars und seiner nebenflusse: eine estandsaufnahme, 157-164

56. Li X, Wu T, Bao H, Liu X, Xu C, Zhao Y, Liu D, Yu H (2017) Potential toxic trace element (PTE) contamination in Baoji urban soil (NW China): spatial distribution, mobility behavior, and health risk. Environ Sci Pollut R. 24:19749-19766. https://doi.org/10.1007/ s11356-017-9526-z 
57. Zhang J, Liu CL (2002) Riverine composition and estuarine geochemistry of particulate metals in China-weathering features, anthropogenic impact and chemical fluxes. Estuar Coast Shelf S. 54:1051-1070. https://doi.org/10.1006/ecss.2001.0879

58. De Wit HE (1987) Stratigraphy and radiometric datings of a midPleistocene transgressive complex in the Agro Ponitino (Central Italy). Geol Romana 26:449-460

59. Hem J D (1985) Study and interpretation of the chemical characteristics of natural water. Department of the Interior, US Geological Survey

60. Ackermann F (1980) A procedure for correcting the grain size effect in heavy metal analyses of estuarine and coastal sediments. Environ Technol 1:518-527. https://doi. org/10.1080/09593338009384008

61. Sena F, Umlauf G (2015) Progetto di Monitoraggio Ambientale su tutto il Territorio della Regione Lombardia (Progetto Soil). https://doi.org/10.2788/250
62. Sappa G, Barbieri M, Andrei F, Ferranti F (2019) Assessment of arsenic mobility in a shallow aquifer from Bevera Valley Basin (Northern Italy). Arab J Geosci 12:678. https://doi.org/10.1007/ s12517-019-4764-7

63. Sappa G, Barbieri M, Andrei F (2020) Natural hazards coming from trace elements natural enrichment: the Bevera Valley Basin (Northern Italy) case history. In: Advances in natural hazards and hydrological risks: meeting the challenge. Springer, Cham, pp 33-36. https://doi.org/10.1007/978-3-030-34397-2_7

Publisher's Note Springer Nature remains neutral with regard to jurisdictional claims in published maps and institutional affiliations. 